\title{
Is dehydroepiandrosterone a hormone?
}

\author{
F Labrie, V Luu-The, A Bélanger, S-X Lin, J Simard, G Pelletier \\ and C Labrie \\ Laboratory of Molecular Endocrinology and Oncology, Laval University Hospital Research Center (CRCHUL) and Laval University, Québec City, \\ Québec G1 V 4 G2, Canada \\ (Requests for offprints should be addressed to F Labrie; Email: fernand.labrie@crchul.ulaval.ca)
}

\begin{abstract}
Dehydroepiandrosterone (DHEA) is not a hormone but it is a very important prohormone secreted in large amounts by the adrenals in humans and other primates, but not in lower species. It is secreted in larger quantities than cortisol and is present in the blood at concentrations only second to cholesterol. All the enzymes required to transform DHEA into androgens and/or estrogens are expressed in a cellspecific manner in a large series of peripheral target tissues, thus permitting all androgen-sensitive and estrogensensitive tissues to make locally and control the intracellular levels of sex steroids according to local needs. This new field of endocrinology has been called intracrinology. In women, after menopause, all estrogens and almost all androgens are made locally in peripheral tissues from DHEA which indirectly exerts effects, among others, on bone formation, adiposity, muscle, insulin and glucose metabolism, skin, libido and well-being. In men, where the secretion of androgens by the testicles continues for life, the contribution of DHEA to androgens has been best
\end{abstract}

evaluated in the prostate where about $50 \%$ of androgens are made locally from DHEA. Such knowledge has led to the development of combined androgen blockade (CAB), a treatment which adds a pure anti-androgen to medical (GnRH agonist) or surgical castration in order to block the access of the androgens made locally to the androgen receptor. In fact, $\mathrm{CAB}$ has been the first treatment demonstrated to prolong life in advanced prostate cancer while recent data indicate that it can permit long-term control and probably cure in at least $90 \%$ of cases of localized prostate cancer. The new field of intracrinology or local formation of sex steroids from DHEA in target tissues has permitted major advances in the treatment of the two most frequent cancers, namely breast and prostate cancer, while its potential use as a physiological HRT could well provide a physiological balance of androgens and estrogens, thus offering exciting possibilities for women's health at menopause.

Journal of Endocrinology (2005) 187, 169-196

\section{Introduction}

Humans, along with the other primates, are unique among animal species in having adrenals that secrete large amounts of the inactive precursor steroids dehydroepiandrosterone (DHEA) and especially DHEA-sulfate (DHEA-S), which are converted into potent androgens and/or estrogens in peripheral tissues (Labrie 1991, Labrie et al. 1995a, 1996b, 1997d, 2000b, 2001, Luu-The 2001) (Fig. 1). In fact, plasma DHEA-S levels in adult men and women are 100-500 times higher than those of testosterone and 1000-10 000 times higher than those of estradiol, thus providing a large reservoir of substrate for conversion into androgens and/or estrogens in the peripheral intracrine tissues which naturally possess the enzymatic machinery necessary to transform DHEA into active sex steroids.
Adrenal secretion of DHEA and DHEA-S increases during adrenarche in children at the age of 6-8 years. Maximal values of circulating DHEA-S are reached between the ages of 20 and 30 years. Thereafter, serum DHEA and DHEA-S levels decrease markedly (Fig. 2) (Migeon et al. 1957, Vermeulen et al. 1982, Orentreich et al. 1984, Bélanger et al. 1994, Labrie et al. 1997e). In fact, at 70 years of age, serum DHEA-S levels are decreased to approximately $20 \%$ of their peak values, while they can decrease by $95 \%$ by the age of $85-90$ years (Migeon et al. 1957).

The marked reduction in the formation of DHEA-S by the adrenals during aging (Migeon et al. 1957, Vermeulen \& Verdonck 1976, Vermeulen et al. 1982, Orentreich et al. 1984, Bélanger et al. 1994, Labrie et al. 1997c) results in a dramatic fall in the formation of androgens and 


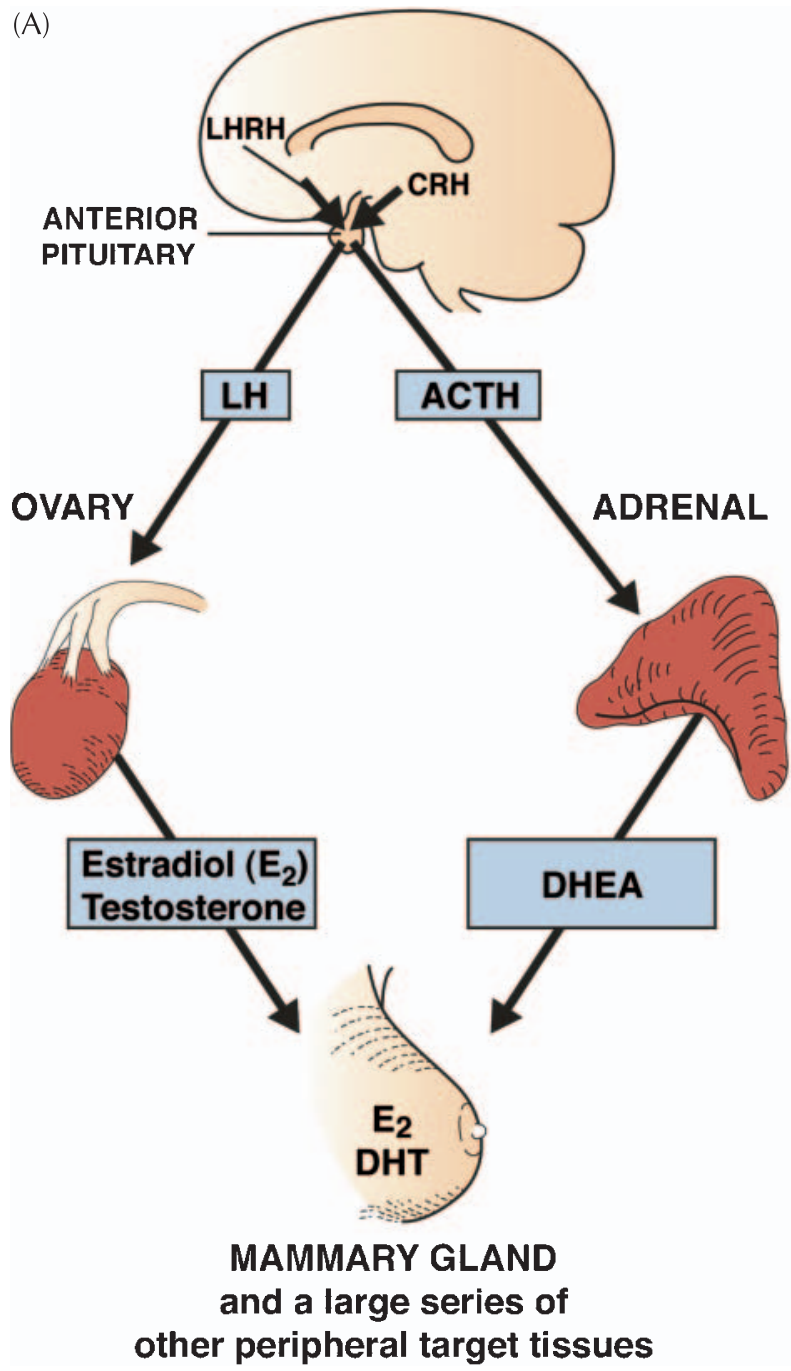

(B) Intact - normal

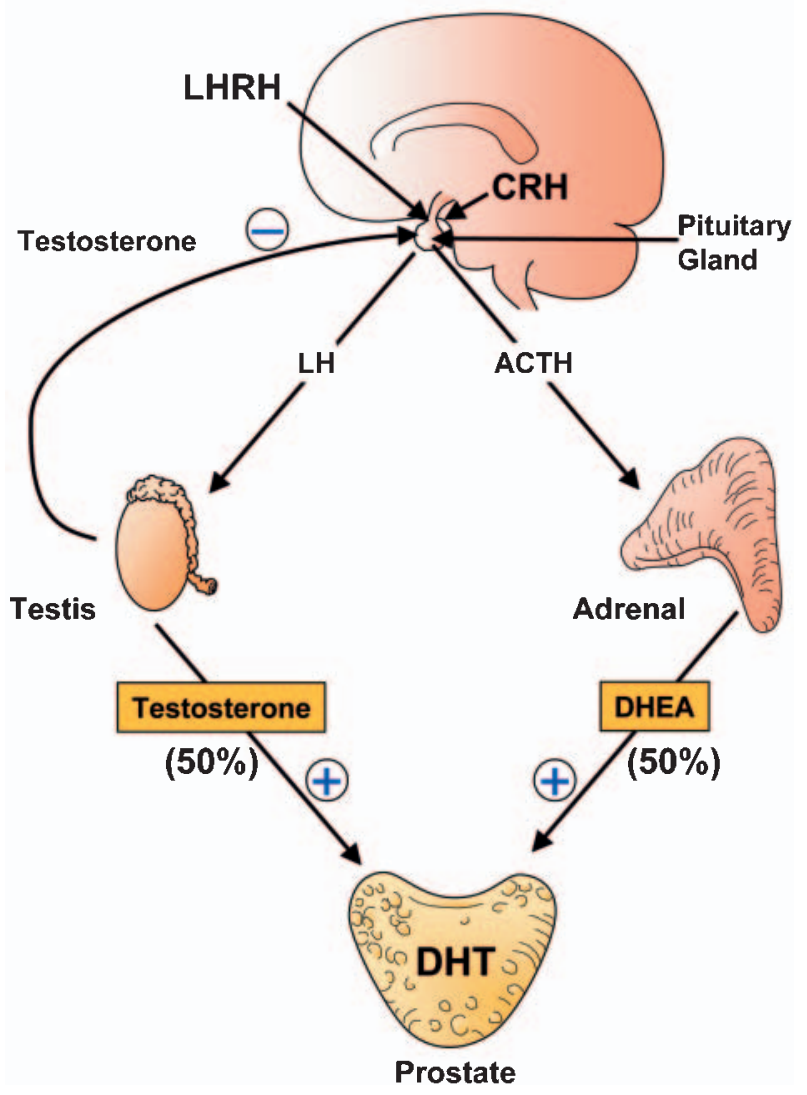

Figure 1 (A) Schematic representation of the role of ovarian and adrenal sources of sex steroids in premenopausal women. After menopause, the secretion of estradiol by the ovaries ceases and then almost $100 \%$ of sex steroids are made locally in peripheral target intracrine tissues. (B) Schematic representation of the role of testicular and adrenal sources of androgens in 60-year-old men. ACTH, adrenocorticotropin; DHEA, dehydroepiandrosterone; DHT, dihydrotestosterone; $\mathrm{E}_{2}$, 17ß-estradiol; LH, luteinizing hormone; LHRH, LH-releasing hormone; $\mathrm{CRH}$, corticotropin-releasing hormone.

estrogens in peripheral target tissues, a situation that has been proposed to be associated with age-related diseases such as insulin resistance (Coleman et al. 1982, Schriock et al. 1988) and obesity (Nestler et al. 1988, MacEwen \& Kurzman 1991, Tchernof et al. 1995). On the other hand, much attention has been given to the benefits of DHEA administered to postmenopausal women, especially on the bone, skin, vaginum and well-being after oral (Morales et al. 1994, Baulieu et al. 2000) and percutaneous (Diamond et al. 1996, Labrie et al. 1997b) administration.

It is thus remarkable that man, in addition to possessing very sophisticated endocrine and paracrine systems, has largely invested in sex steroid formation in peripheral tissues (Labrie et al. 1985, 1988, 1997a, Labrie 1991). In fact, while the ovaries and testes are the exclusive sources of androgens and estrogens in lower mammals, the situation is very different in man and higher primates, where active sex steroids are in large part or wholly synthethized locally in peripheral tissues, thus providing target tissues with the appropriate controls which adjust the formation and metabolism of sex steroids to local requirements.

Transformation of the adrenal precursor steroids DHEA-S and DHEA into androgens and/or estrogens in peripheral target tissues depends upon the level of expression of the various steroidogenic and metabolizing enzymes in each cell of these tissues. This sector of endocrinology that focuses on the intracellular hormone formation and action has been called intracrinology 

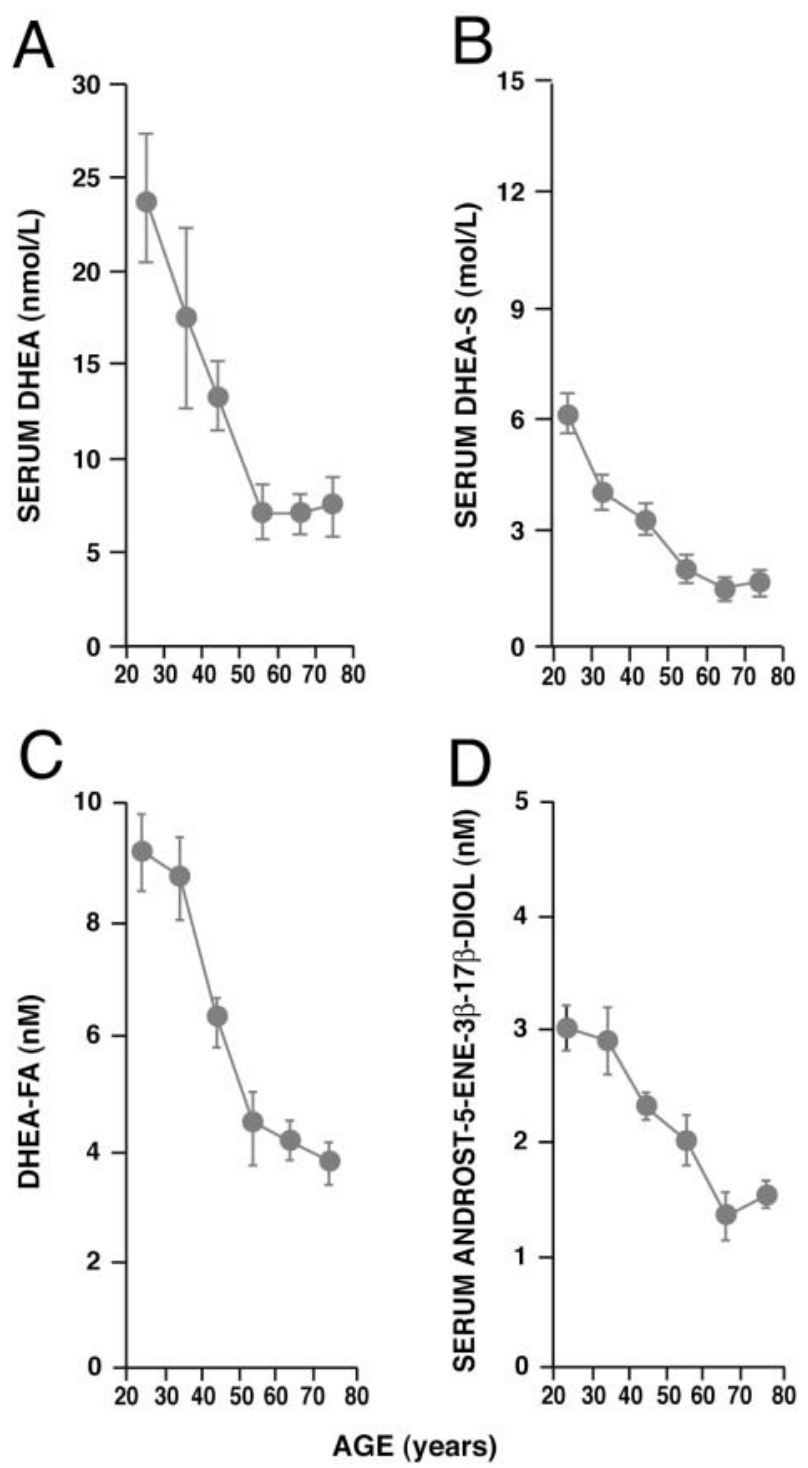

Figure 2 Effect of age (20-30 to 70-80 years old) on serum concentration of (A) DHEA, (B) DHEA-S, (C) DHEA-fatty acid esters (DHEA-FA) and (D) androst-5-ene-3 $\alpha, 17 \beta$-diol (5-diol) in women (Labrie et al. 1997c: reproduced with permission from Journal of Clinical Endocrinology and Metabolism).

(Labrie et al. 1988, Labrie 1991) (Fig. 3). This situation of a high secretion rate of adrenal precursor sex steroids in men and women is thus completely different from all animal models used in the laboratory, namely rats, mice, guinea pigs and all others (except monkeys), where the secretion of sex steroids takes place exclusively in the gonads (Labrie et al. 1985, 1988, 1997a, Bélanger et al. 1989). One explanation for the delayed progress in the field of formation of sex steroids in peripheral target tissues or intracrinology is the fact that the adrenals of the animal models usually used do not secrete significant amounts of adrenal precursor sex steroids, thus focusing all attention on the testes and ovaries as the exclusive sources of androgens and estrogens. The term intracrinology was thus coined (Labrie et al. 1988) to describe the synthesis of active steroids in peripheral target tissues where the action is exerted in the same cells where synthesis takes place without release of the active steroids in the extracellular space and general circulation (Labrie 1991).

Although orchiectomy, estrogens or gonadotropinreleasing hormone $(\mathrm{GnRH})$ agonists or antagonists (through blockade of secretion of bioactive LH) cause a 90-95\% reduction in the concentration of circulating testosterone (Labrie et al. 1980, 1985, Waxman et al. 1983, Moghissi et al. 1984) (Fig. 4A), a much smaller effect is seen on the only parameter that directly reflects intra-tissular androgenic action, i.e. the intra-prostatic concentration of the potent androgen DHT. In fact, intra-prostatic DHT levels are reduced by only $50-70 \%$ following medical or surgical castration (Labrie et al. 1985, Bélanger et al. 1986) (Fig. 4A). Moreover, as illustrated in Fig. 4B, the plasma concentrations of the two main metabolites of androgens, namely ADT-G and $3 \alpha$-diol-G, remain at $28 \%$ and $37 \%$ of control, respectively, after castration in adult men (Bélanger et al. 1986), thus reflecting the high levels of adrenal precursors converted into DHT in the prostate. In agreement with the abovementioned clinical findings, we have observed that plasma concentrations of DHEA and 4-dione comparable with those found in adult men exert potent stimulatory effects on androgen-dependent growth and gene expression in the rat ventral prostate (Labrie et al. 1988, 1989).

In women, the role of the adrenal precursors DHEA-S, DHEA and 4-dione in the peripheral formation of estrogens is even more important than the situation in men for androgens. In fact, in men, androgen secretion by the testes continues at a high level through life while, in women, estrogen secretion by the ovaries completely ceases at menopause, thus leaving the adrenals as the only source of sex steroids. In fact, the best estimate is that the intracrine formation of estrogens in peripheral tissues in women accounts for $75 \%$ of all estrogens before menopause, and close to 100\% after menopause (Adams 1985, Labrie et al. 2003a). In addition to $\mathrm{E}_{2}$, another important but still largely unrecognized estrogen is androst-5-ene$3 \beta, 17 \beta$-diol (5-diol). This steroid of adrenal origin has in fact been shown to exert direct estrogenic effects in both normal and malignant estrogen-sensitive tissues at concentrations found in the circulation of normal adult women (Adams 1985, Poulin \& Labrie 1986, Simard et al. 1988).

Discovery of the castration effect of GmRH agonists (Labrie et al. 1980) has rendered possible the 100\% effective, yet reversible, abrogation of testicular and ovarian function, a uniquely well-tolerated approach that has now been available for 25 years for the therapy of androgen- and estrogen-sensitive diseases, especially prostate, breast and uterine cancer. These cancers account for 


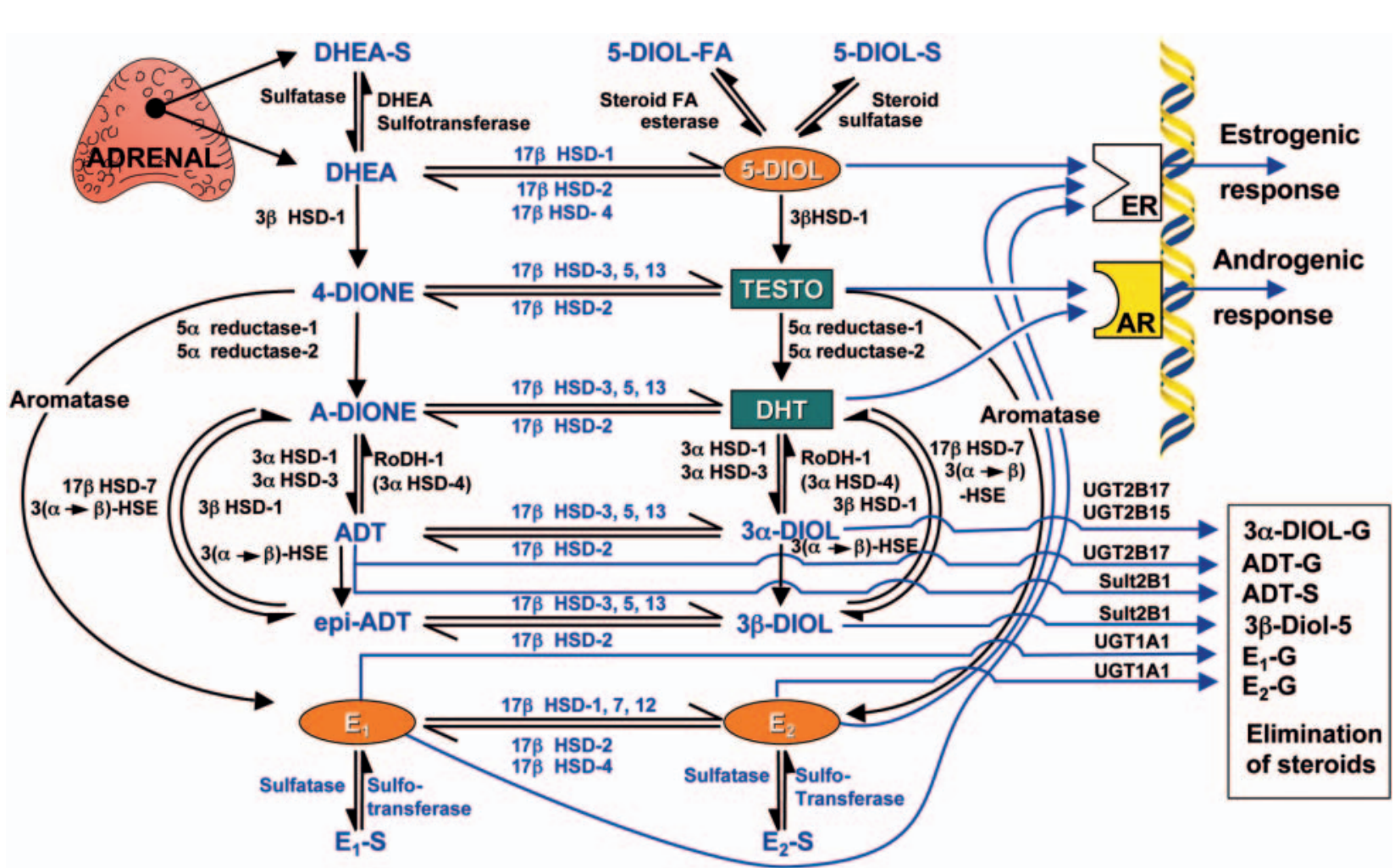

Figure 3 Human steroidogenic and steroid-inactivating enzymes in peripheral intracrine tissues. 4-DIONE, androstenedione; A-DIONE, 5-alpha-androstane-3,17-dione; ADT, androsterone; epi-ADT, epiandrosterone; $E_{1}$, estrone; $E_{1}-S$, estrone sulfate; 5-DIOL-FA,

androst-5-ene-3alpha, 17beta-diol fatty acid; 5-DIOL-S, androst-5-ene-3alpha,17beta-diol sulphate; HSD, hydroxysteroid dehydrogenase; TESTO, testosterone; RoDH-1, Ro dehydrogenase 1; ER, estrogen receptor; AR, androgen receptor; UGT2B28, uridine glucuronosyl transferase 2B28; Sult2B1, sulfotransferase 2B1; UGT1A1, uridine glucuronosyl transferase 1A1.

$37 \cdot 0 \%$ of all new cancers estimated to be diagnosed in 2005 in the USA (Jemal et al. 2005). However, the impact of the precursors of adrenal origin that continue to be secreted and transformed into androgens and/or estrogens in peripheral tissues, including the prostate, after medical or surgical castration, needs to be controlled in order to achieve the most efficient endocrine therapy needed to treat these cancers (Labrie 2002). Definitive proof of the importance of the androgens made in the human prostate (intracrinology) is illustrated by the fact that the first demonstration of a prolongation of life in prostate cancer in randomized studies was obtained when the effect of an LHRH agonist (medical castration) associated with a pure anti-androgen (in order to simultaneously block the androgens of adrenal origin) was found to be superior to the effect of an LHRH agonist alone (Labrie et al. 1982, Crawford et al. 1989, Bennett et al. 1999, Prostate Cancer Triallists' Collaborative Group 2000). Most importantly, the same treatment applied at the localized stage of the disease has led to a probable cure of the disease in more than $90 \%$ of patients (Labrie et al. 2002).

Since ovarian estrogen secretion ceases at menopause, the major role of peripheral estrogen formation in post- menopausal women is clearly demonstrated, as mentioned above, by the observation of the major benefits of aromatase inhibitors in advanced breast cancer in postmenopausal women (Nabholtz et al. 2000, Goss et al. 2003, Mouridsen et al. 2003) as well as by the findings of a $76 \%$ decrease in breast cancer incidence in postmenopausal osteoporotic women who received the selective estrogen receptor modulator (SERM) raloxifene for 3 years (Cummings et al. 1999).

It should also be noted that the importance of the intracrine formation of androgens and estrogens extends to non-malignant diseases such as acne, seborrhea, hirsutism and androgenic alopecia as well as to osteoporosis and vaginal atrophy (Cusan et al. 1994, Labrie et al. 1997b). Another example of the relevance of intracrinology in non-malignant diseases is endometriosis (Bulun et al. 2000). In this regard, it has recently been demonstrated that aromatase is expressed aberrantly in endometriosis, while this activity is not detectable in the normal endometrium. Furthermore, another abnormality in this disease is the deficient expression of type $217 \beta-\mathrm{HSD}$, thus impairing the inactivation of $\mathrm{E}_{2}$ into $\mathrm{E}_{1}$. Consequently, the increased formation of $\mathrm{E}_{2}$ by aromatase coupled with 

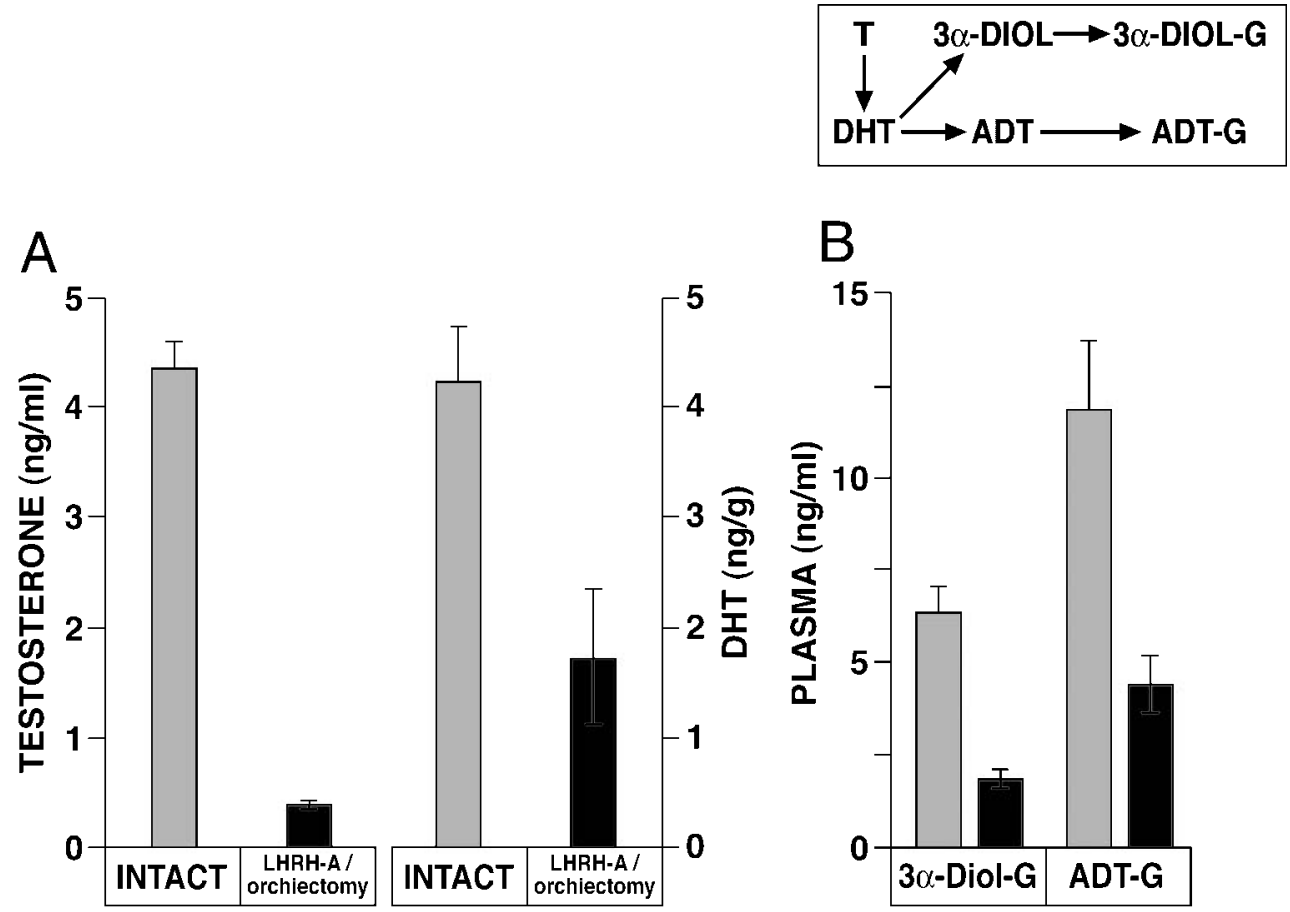

Figure 4 (A) Effect of castration on the serum levels of testosterone (T), on one hand, and on the concentration of the active androgen DHT remaining in prostatic cancer tissue after castration, on the other hand. Note the relatively small effect (approximately 60\%) of castration on intra-prostatic DHT concentration as compared with the $90 \%$ fall in serum testosterone. LHRH-A, LHRH agonist. (B) Plasma concentrations of androstane- $3 \alpha, 17 \beta$-diol glucuronide ( $3 \alpha$-Diol-G) and androsterone glucuronide (ADT-G) in 20 intact (yellow bars) and 18 castrated (gold bars) men with prostate cancer. Patients were of similar age.

the decreased inactivation of $\mathrm{E}_{2}$ by type 2 17ß-HSD leads to increased stimulation of the endometrium and endometriosis.

It is increasingly apparent that mammary cells possess complex regulatory mechanisms that allow for the strict control of the intracellular levels of both stimulatory and inhibitory sex steroids. For instance, our data show that DHT favors the degradation of $E_{2}$ into $E_{1}$, thus suggesting that the potent anti-proliferative activity of DHT in $\mathrm{E}_{2}$-stimulated ZR-75-1 human breast cancer cells is, at least partially, exerted on $17 \beta-H S D$ activity (Adams 1985, Poulin et al. 1988, 1989, Couture et al. 1993). Conversely, we have found that estrogens cause a marked increase in the production of the glucuronidated androgen metabolites $3 \alpha$-diol-G, 3 $\beta$-diol-G and ADT-G in MCF-7 cells, thus decreasing the inhibitory androgenic activity (Roy et al. 1992). In fact, since glucuronidation is the predominant route of androgen inactivation, androgen-inactivating enzymes constitute an important site of regulation of breast cancer growth.

The skin is also an important target of intracrine sex steroid action. In fact, it is well recognized that the skin synthesizes androgens from inactive steroid precursors and that acne, seborrhea, hirsutism and androgenic alopecia are associated with excess androgens (Mauvais-Jarvis et al.
1969, Milne 1969, Wilson \& Walker 1969, Bingham \& Shaw 1973, Liang et al. 1983, Labrie 1991, Dumont et al. 1992b, Cusan et al. 1994). In fact, increased local biosynthesis of the potent androgen DHT from the weaker androgen testosterone by $5 \alpha$-reductase has been suggested to be one of the mechanisms involved (Kuttenn et al. 1979). Although a series of studies have addressed the role of sex steroids in the control of hair growth and sebaceous gland physiology, the importance of skin as a site of regulated steroid biosynthesis and metabolism has received little attention. The presence of $3 \beta-\mathrm{HSD}$ in rat skin has been reported (Flamigni et al. 1970, Muir et al. 1970) and local rat skin steroidogenesis has also been suggested to modulate sebaceous gland activity (Ebling et al. 1971). These early pioneering studies can now be carried further using the molecular biology tools that have become available (Zhao et al. 1990, 1991). Since human skin is composed of various cell populations showing sensitivity to androgens, especially the epidermis, hair follicles, sebaceous glands, sweat glands and dermis, antibodies developed against fragments of type $15 \alpha$-reductase have been used to localize the enzyme by immunohistochemistry (Luu-The et al. 1994). We have also found that $5 \alpha-$ reductase is expressed in sweat and sebaceous glands, as well as in the epidermal cell layers, thus providing the 
molecular basis for the important role of androgens in human skin and its appendages.

\section{Intracrinology and its steroidogenic and steroid-inactivating enzymes}

\section{Steroidogenic enzymes}

As mentioned above, transformation of the adrenal precursor steroids DHEA and DHEA-S into androgens and/or estrogens in peripheral target tissues depends upon the level of expression of the various steroidogenic and metabolizing enzymes in each cell of these tissues. Knowledge in this area has recently made major progress with the elucidation of the structure of most of the tissue-specific genes that encode the steroidogenic enzymes responsible for the transformation of DHEA and DHEA-S into androgens and/or estrogens in peripheral intracrine tissues (Labrie et al. 1988, 1992b, 1995b, 1997a, Peltoketo et al. 1988, Luu-The et al. 1989a, 1995b, Andersson \& Russel 1990, Lachance et al. 1990, 1991, Labrie 1991, 2000b, Rhéaume et al. 1991, Pelletier et al. 1992, Milewich et al. 1993, Martel et al. 1994, Adamski et al. 1995) (Fig. 3).

Human 3 3 -HSD isoenzymes and their genes Despite its essential role in the biosynthesis of all classes of hormonal steroids, the structure of the $3 \beta$-hydroxysteroid dehydrogenase $/ \Delta^{5}-\Delta^{4}$-isomerase gene family, hereafter called $3 \beta-H S D$, was only elucidated in 1989 (Luu-The et al. 1989a, Lachance et al. 1990, 1991, Rhéaume et al. 1991). The membrane-bound enzyme $3 \beta-H S D$ catalyzes an essential step in the transformation of all 5-pregnen$3 \beta$-ol and 5 -androsten-3 $\beta$-ol steroids into the corresponding $\Delta 4-3-$ keto-steroids, namely progesterone, as well as the precursors of all androgens, estrogens, glucocorticoids and mineralocorticoids.

In contrast with the results obtained using microsomes and purified enzymes which show that $3 \beta-\mathrm{HSD}$ catalyzes the interconversion of $3 \beta$-hydroxy- and 3-keto- $5 \alpha-$ androstane steroids (Luu-The et al. 1991), when intact transfected cells in culture are used without the addition of cofactors, an experimental procedure which better mimics the physiological conditions, $3 \beta-H S D$ catalyzes almost exclusively the oxidation of $3 \beta$-hydroxy- into 3 -keto- $5 \alpha-$ androstane steroids (Huang \& Luu-The 2001b) while the reverse reductive reaction is catalyzed by another enzyme, namely, $3(\alpha \rightarrow \beta)$-HSE (Huang \& Luu-The 2000, 2001b) and type 7 17 $\beta$-HSD (Liu et al. 2005).

Not only is $3 \beta-$ HSD found in the classical steroidogenic tissues (placenta, adrenal cortex, ovary and testis), but also in several peripheral tissues, including the skin, adipose tissue, breast, lung, endometrium, prostate, liver, kidney, epididymis and brain (Labrie et al. 1992a, Pelletier et al. 1992, Milewich et al. 1993, Martel et al. 1994), thus catalyzing the first step in the intracrine transformation of DHEA into 4-dione, the precursor of both androgens and estrogens. The existence of multiple members of the $3 \beta$ HSD gene family offers the unique possibility of tissueand/or cell-specific expression of this enzymatic activity.

Following purification of $3 \beta-H S D$ from human placenta and development of antibodies against the enzyme in rabbits (Luu-The et al. 1990b), we have isolated and characterized a first 3 $\beta-H S D$ cDNA type (Luu-The et al. 1989a) and its corresponding gene (Lachance et al. 1990). The second $3 \beta-H S D$ cDNA type, which corresponds to the almost exclusive mRNA species expressed in the adrenals and gonads, was chronologically designated human type $23 \beta-H S D$ (Rhéaume et al. 1991). The structure of the corresponding human type $23 \beta-\mathrm{HSD}$ gene has also been elucidated (Lachance et al. 1991). The human $3 \beta-H S D$ genes corresponding to human cDNAs types 1 and 2 contain four exons and three introns within a total length of $7 \cdot 7-7 \cdot 8 \mathrm{kbp}$. These genes were assigned by in situ hybridization to the $\mathrm{p} 13 \cdot 1$ region of chromosome 1 and are closely linked to D1S514 located at 1-2 cM of the centromeric marker D1Z5 (Morissette et al. 1995).

We have observed that mutations in the type $23 \beta$-HSD gene are responsible for classic $3 \beta-H S D$ deficiency, a form of congenital adrenal hyperplasia that impairs sterodogenesis in both the adrenals and gonads (Rhéaume et al. 1992, Simard et al. 1993, 1995). However, the absence of mutations in the type 1 gene provided the long-awaited molecular explanation for the persistence of peripheral steroidogenesis in these type $23 \beta$-HSD-deficient patients, thus demonstrating the importance of peripheral sex steroid formation or intracrinology.

Human 17ß-HSDs The $17 \beta-H S D$ s are responsible for the formation and inactivation of all active androgens and estrogens (Fig. 3). As discussed above for $3 \beta-\mathrm{HSD}$, until relatively recently $17 \beta-H S D$ s as well as almost all other dehydrogenases were considered to be reversible enzymes that catalyze the interconversion of substrates and products, mainly because the enzymatic activity was usually characterized using tissue homogenates, subfractions or purified proteins with added oxidized (NAD+, NADP+) or reduced (NADH, NADPH) cofactors. These exogenous cofactors drive the reaction in the oxidative or reductive direction depending upon their oxidized or reduced state respectively. However, using a more physiologically relevant method of enzymatic activity analysis, namely intact transfected cells in culture without the addition of exogenous cofactors, the transfected enzyme catalyzes the reaction in a unidirectional manner (Luu-The et al. 1995a, 2001, Dufort et al. 1999, Huang \& Luu-The 2000, 2001b). These findings agree with the isolation of multiple types of $17 \beta-$ HSDs where six catalyze the reductive reaction (types 1, 3, 5, 7, 12 and 13) and four catalyze the oxidative reaction (types 2, 4, 6 and 8 ).

The readers are referred to original manuscripts and reviews for information on type 1 (Peltoketo et al. 1988, 1992, Luu-The et al. 1989b, 1990a, Dumont et al. 1992a, 
Lin et al. 1992, Zhu et al. 1993, Breton et al. 1994, Ghosh et al. 1995), type 2 (Luu-The et al. 1989b, Wu et al. 1993, Andersson et al. 1995), type 3 (Geissler et al. 1994), type 4 (Leenders et al. 1994, Adamski et al. 1995, de Launoit \& Adamski 1999), type 6 (Biswas \& Russell 1997), type 7 (Duan et al. 1996, Nokelainen et al. 1998, Krazeisen et al. 1999) and type 8 (Aziz et al. 1993, Kikuti et al. 1997, Luu-The 2001) 17 $\beta$-HSDs. The roles of types 9, 10 and $1117 \beta-H S D s$ in the human remain to be determined while human types 12 and $1317 \beta-H S D s$ are at a final stage of characterization (Liu et al. 2005). We will limit our review to type $517 \beta-\mathrm{HSD}$, an enzyme which plays an important role in the peripheral formation of androgens in both men and women.

Type $517 \beta$-HSD Although type $317 \beta$-HSD synthesizes testosterone from 4-dione in the Leydig cells of the testes, thus providing approximately $50 \%$ of the total amount of androgens in men, the same enzymatic reaction is catalyzed in the peripheral target tissues in both men and women as well as in the ovary by a different enzyme, namely type 5 17ß-HSD (Dufort et al. 1999). This enzyme is highly homologous with types 1 and $33 \alpha-\mathrm{HSDs}$ as well as 20 $\alpha$-HSD (Dufort et al. 1999) and thus belongs to the aldo-keto reductase family.

In the postmenopausal ovary, hypertrophied stromal cells are localized mainly at the periphery and hilus (Russell \& Bannatyne 1989). These stromal cells contain both $3 \beta-H S D$ and type $517 \beta-H S D$, thus permitting the transformation of DHEA into 4-dione and then into testosterone. The amount of stromal hyperplasia in postmenopausal ovaries is correlated with the ovarian vein levels of 4-dione and testosterone (Sluijmer et al. 1998). These hyperplastic stromal cells are thus responsible for the synthesis of 4-dione and testosterone in the postmenopausal ovary.

Type $517 \beta-H S D$ is not only expressed in the ovary but it is also present in a large series of peripheral tissues including the mammary gland. The epithelium lining the acini and ducts of the mammary gland is composed of two layers, an inner epithelial layer and an outer discontinuous layer of myoepithelial cells. By immunocytochemistry, $3 \beta-H S D$ is seen in the epithelial cells of acini and ducts as well as in stromal fibroblasts (Fig. 5A). Immunostaining is also observed in the walls of blood vessels, including the endothelial cells. In the positive cells, the labeling is mainly cytoplasmic. No significant labeling could be detected in the myeopithelial cells. As shown in Fig. 5B, immunostaining for type $517 \beta-\mathrm{HSD}$ gives results almost superimposable onto those obtained for $3 \beta-\mathrm{HSD}$, the cytoplasmic labeling being observed in both epithelial and stromal cells as well as in blood vessel walls (Pelletier et al. 1999). Studies performed at the electron microscopic level revealed that, in sections stained for $3 \beta-H S D$ or type 5 $17 \beta-H S D$, labeling was not associated with any specific membrane-bound organelles in the different reactive cell types (Pelletier et al. 2001). The type $517 \beta-H S D$ structure has an eight-stranded $\alpha / \beta$-barrel in its center, a typical folding motif in a large family of enzymes, with each inner $\beta$-strand connected to an outer $\alpha$-helix. In addition, two $\beta$-strands (B1 and B2) form a $\beta$-hairpin turn preceding $\beta 1$ of the barrel, blocking the $\mathrm{N}$ terminus of the $\beta$-barrel; one $\alpha$-helix (H1) interrupts between $\alpha 7$ and $\beta 8$ and another one (H2) follows $\alpha 8$ at the $\mathrm{C}$ terminus. Four large loops, namely loop-A (residues 24-33), loop-B (residues 117-143), loop-C (residues 217-238) and loop-D (residues 301-323), help to form the substrate and cofactor-binding sites at the C-terminal end of the $\alpha / \beta$ barrel (Fig. 6). In addition, the refined models from the two ternary complexes have a root mean squared deviation of $0.61 \AA$ for $311 \mathrm{C} \alpha$ atoms from the enzyme protein and a maximum deviation of $3 \cdot 1 \AA$ at $\mathrm{C} \alpha$ of Gly315 (Qiu et al. 2004).

Human 5a-reductase isoenzymes The enzyme $5 \alpha-$ reductase catalyzes the $5 \alpha$-reduction of 4 -dione, testosterone and other 4-ene-3-keto-steroids to the corresponding $5 \alpha$-dihydro-3-keto-steroids. The best known role of this enzyme is the transformation of testosterone into DHT, the most potent androgen, which is responsible for the differentiation of the male external genitalia and prostate as well as virilization at puberty. The major impact of $5 \alpha$-reductase in men, however, is its role in prostate cancer and benign prostatic hyperplasia. Two types of human steroid $5 \alpha$-reductases, chronologically identified as type 1 and type 2, were isolated from human prostatic cDNA libraries (Andersson \& Russel 1990, Andersson et al. 1991). The structure of the human type $15 \alpha-$ reductase gene was first elucidated by Jenkins et al. (1991). This gene is not responsible for $5 \alpha$-reductase deficiency, and is relatively insensitive to the inhibitor finasteride (Andersson et al. 1991). Type $25 \alpha$-reductase, on the other hand, is the isozyme responsible for male pseudohermaphroditism from $5 \alpha$-reductase deficiency and is sensitive to finasteride (Andersson et al. 1991, Wilson et al. 1993).

Considering the crucial role of type $25 \alpha$-reductase, we have elucidated the structure of its corresponding gene (Labrie et al. 1992b). The type 2 5a-reductase gene contains five exons and four introns and shows splicing sites identical to those of the type 1 gene. Its coding region shares $57 \%$ homology with that of the type $15 \alpha$-reductase gene. Type $15 \alpha$-reductase is the predominant form expressed in human skin (Luu-The et al. 1994).

\section{Steroid-inactivating enzymes}

There is also good evidence that the DHT formed in peripheral tissues is essentially metabolized locally before its appearance in the circulation (Horton \& Lobo 1986, Horton 1992). Phase I DHT catabolites include androstanedione, ADT, epiandrosterone, 3 $\alpha$-diol and androstane- $3 \beta, 17 \beta$-diol, which are formed by the action 

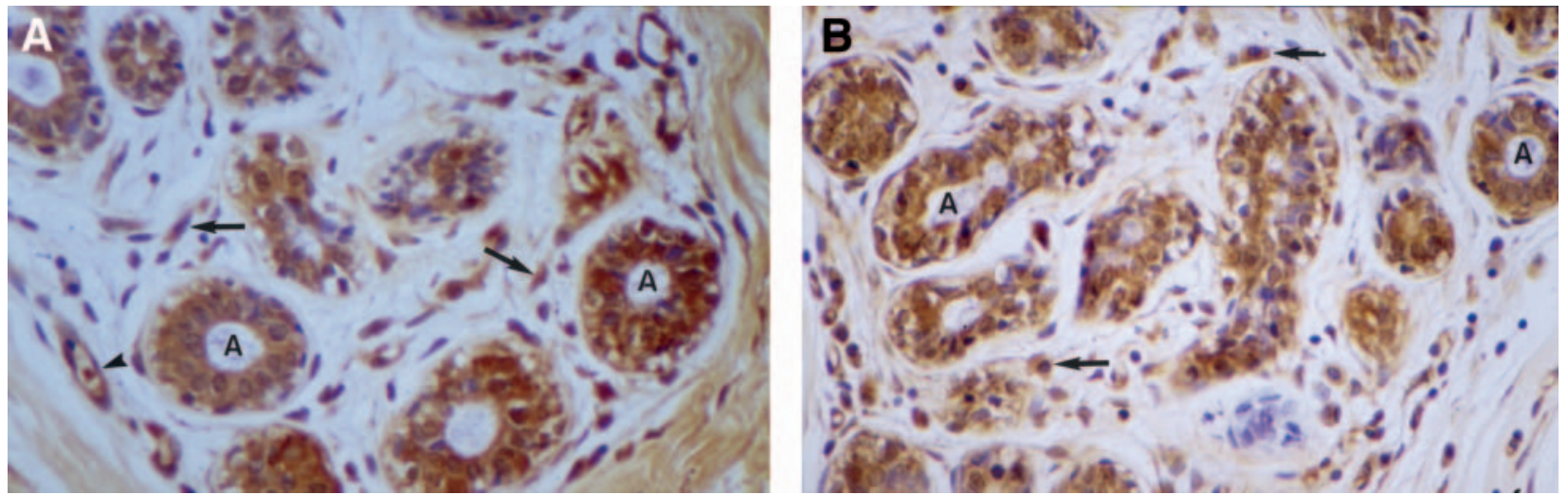

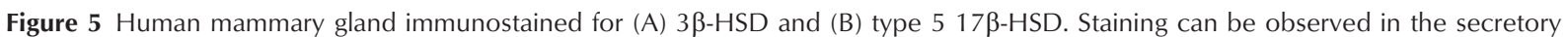
epithelial cells of acini (A). Stromal cells (arrows) and capillaries (arrow heads) are also labeled. Magnification $\times 350$.

of a series of $3 \alpha / \beta$-HSDs and $17 \beta$-HSD isoforms (Fig. 3) (Labrie et al. 2000a, Andersson 2001, Dufort et al. 2001, Luu-The 2001). However, most if not all of the androgentarget tissues express HSD isoforms that are capable of back converting the phase I metabolites into DHT, thus suggesting that a fine regulation of these enzymes is extremely important for controlling the concentration of DHT in androgen-target tissues.

The serum levels of the conjugates are increased after oral or topical administration of DHEA or 4-dione in the

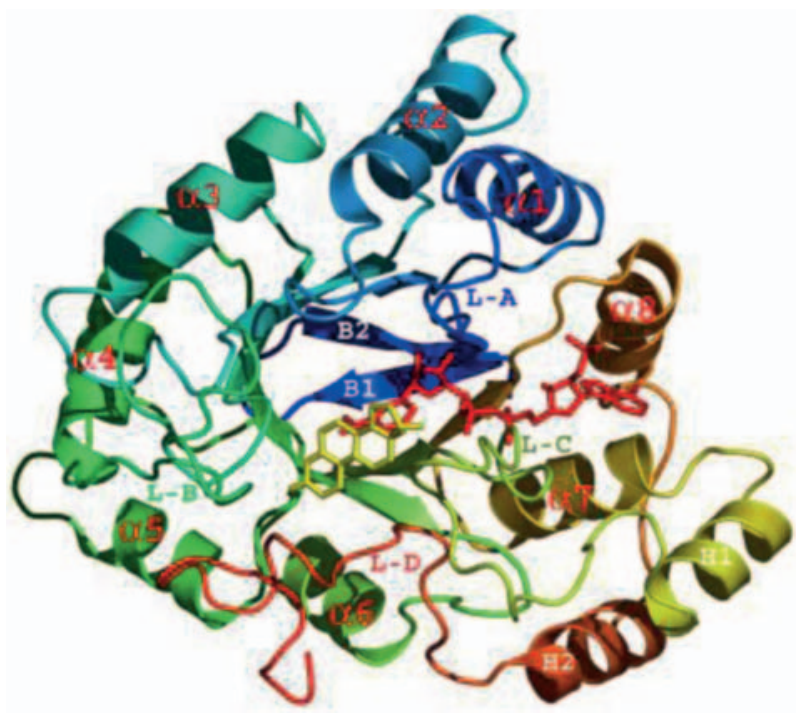

Figure 6 Representation of type $517 \beta-\mathrm{HSD} /$ testosterone/NADP structure. The testosterone molecule is displayed in yellow and the NADP molecule in red. Two $\beta$-strands (B1 and B2, colored in deep blue) form a $\beta$-hairpin turn at the $N$ terminus of the $\beta$-barrel. Two additional $\alpha$-helixes $(\mathrm{H} 1$ and $\mathrm{H} 2)$ are colored in yellow and brown. Four large loops, namely loop-A ( $L-A$, blue), loop-B ( $L-B$, green), loop-C ( $\mathrm{L}-\mathrm{C}$, light green) and loop-D ( $\mathrm{L}-\mathrm{D}$, red), form the substrate and cofactor-binding sites at the C-terminal end of the $\alpha / \beta$-barrel. The figure was generated with program PyMOL (Qiu et al. 2004). presence of no change or minimal change in the blood levels of non-conjugated androgen metabolites (Labrie et al. 1997a). These observations further support the concept that $5 \alpha$-reduced androgen glucuronides found in the circulation are produced in situ in peripheral tissues after conversion of the adrenals and/or gonadal steroid precursors into DHT first and, subsequently, into phase I DHT metabolites without release of these intermediate steroid precursors and metabolites into the circulation (Horton \& Lobo 1986, Labrie 1991, Horton 1992, Labrie et al. 2003a). Consequently, the glucuronidation of phase I metabolites by UDP-glucuronosyltransferase (UGT) enzymes in androgen-sensitive tissues should be considered as the end of the androgenic signal. In the circulation, two major phase II DHT metabolites, namely ADT-G and 3a-diol-G, have been identified, but low amounts of DHT-G and 3ß-diol-G were also detected (Labrie et al. 1997a).

\section{UGT2B enzymes in the human prostate}

Conjugation of compounds, including steroids, by glucuronidation is a pathway that has been found in all vertebrates studied to date. More than 45 different UGT cDNA clones have been isolated from seven mammalian species, including 18 human UGT clones (Mackenzie et al. 1997, Levesque et al. 2001).

In the human prostate, the alveoli are composed of two cell types. The basal cells are small cells lining the periphery of the alveoli, whereas the luminal cells are large columnar cells in contact with the alveolar lumen. The two cell types play distinct roles in androgen formation and action (Fig. 7). The expression of type $13 \beta-H S D$, type 5 $17 \beta-$ HSD and types 1 and $25 \alpha$-reductase is detected in the basal cells, whereas, in the luminal cells, where the androgen receptor is exclusively observed, mostly $5 \alpha-$ reductase activity is found (Pelletier et al. 1998, 2001). After castration, DHT concentrations in the prostate are 
reduced by $50-60 \%$, thus indicating that testosterone precursors, such as DHEA, are responsible for an important proportion of DHT in the prostate (Dufort et al. 1999). It is reasonable to suggest that DHT is formed locally in luminal cells from testosterone, which is provided by the circulation and/or metabolism of circulating adrenal steroid precursors (DHEA and 4-dione) in basal cells. Enzymes of the phase I DHT catabolism are also present in basal cells, but they are not detected in luminal cells, which occupy the largest proportion of the human prostate (Huang \& Luu-The 2000, 2001a, Dufort et al. 2001). This absence of phase I catabolic enzymes in luminal cells favors large concentrations of DHT. Indeed, DHT concentrations in the prostate exceed by almost tenfold those of testosterone and phase I DHT metabolites (Bélanger et al. 1989, 1990). The two-cell mechanism provides the basis for the specific control of testosterone and DHT levels in the prostatic tissue.

In agreement with the presence of conjugating activity in this tissue, large concentrations of $3 \alpha-$ diol-G and ADT-G were also reported (Pelletier et al. 2001). Finally, the expression of UGT2B15 and UGT2B17 was subsequently established in the prostate (Turgeon et al. 2001). The UGT2B17 protein is detected in basal cells, whereas UGT2B15 is only observed in luminal cells (Barbier et al. 2000). It is probable that $3 \alpha$-diol and ADT formed in basal cells are easily converted to glucuronides by UGT2B17, whereas the action of UGT2B15 would be limited to DHT in the luminal cells. Taking into account the low levels of UGT2B15 protein found in the prostate, this situation favors high concentrations of DHT in this tissue, in agreement with previous biochemical observations on the intra-prostatic levels of DHT (Fig. 4). In addition, because the affinity of DHT for the androgen receptor is approximately 1000-fold higher than that for UGT2B15, it is believed that UGT2B15 might conjugate only a fraction of the accumulated DHT formed in the luminal cells.

\section{Role of DHEA in women}

There is no medical problem related to women's health with a higher negative impact on morbidity (and frequently mortality) than menopause, a condition closely associated with declining sex steroid availability. The most widely recognized fact concerning menopause is that there is a progressive decrease and finally a rapid arrest of estrogen secretion by the ovaries. The cessation of ovarian estrogen secretion is illustrated by the marked decline in circulating $\mathrm{E}_{2}$ levels. This easily measurable change in circulating $\mathrm{E}_{2}$ levels coupled with the demonstrated beneficial effects of exogeneous estrogens on menopausal symptoms (Grady et al. 1992, Greendale \& Judd 1993, Lomax \& Schonbaum 1993, Archer et al. 1999) and bone resorption (Weiss et al. 1980, Christiansen et al. 1982, Genant et al. 1990, Harris et al. 1991, Grady et al. 1992,
Field et al. 1993, Lindsay 1993, Archer et al. 1999, Women's Health Initiative 2002) has focused most of the efforts of HRT on various forms of estrogens as well as on combinations of estrogen and progestin in order to avoid the risk of endometrial cancer induced by estrogens administered alone.

The almost exclusive focus on the role of ovarian estrogens in women's reproductive physiology has removed attention from the dramatic $70 \%$ fall in circulating DHEA which already occurs between the ages of 20 to 30 and 40 to 50 years (Migeon et al. 1957, Vermeulen \& Verdonck 1976, Vermeulen et al. 1982, Orentreich et al. 1984, Bélanger et al. 1994, Labrie et al. 1997d) (Fig. 2). In fact, since DHEA is transformed to both androgens and estrogens in peripheral tissues, such a fall in serum DHEA and DHEA-S explains why women at menopause are not only lacking estrogens but are also likely to have been deprived of androgens for a few years, as illustrated by the 50-60\% decrease in serum ADT-G (Labrie et al. 1997c) (Fig. 2).

In a recent study nine androgens and their precursors and metabolites were measured by gas chromatographymass spectrometry and liquid chromatography-tandem mass spectrometry in serum samples from 377 healthy postmenopausal women aged 55-65 years and 47 normally cycling 30- to 35-year-old premenopausal women. A decrease of $60 \%$ was then observed in the sum of ADT-G and $3 \alpha$-diol-G while serum DHEA was decreased by $54 \%$ in postmenopausal compared with premenopausal women (F Labrie and A Bélanger, unpublished data). Such findings based upon mass spectrometry data provide strong support and confirm our previous observations (Labrie et al. 1997c). Serum testosterone, on the other hand, did not decrease significantly from $0.18 \pm 0.07$ in premenopausal to $0.14 \pm 0.07 \mathrm{ng} / \mathrm{ml}$ in postmenopausal women.

Since the serum levels of ADT-G and $3 \alpha$-diol-G in women are $70 \%$ of those found in men of the same age while serum testosterone in women compared with men is only about $3 \%(0 \cdot 15 \mathrm{ng} / \mathrm{ml}$ in women versus $4.5 \mathrm{ng} / \mathrm{ml}$ in men), it is clear that serum testosterone is not a valid marker of androgenicity in women. This situation is somewhat analogous to the situation in castrated men where castration causes a 90-95\% reduction in the concentration of serum testosterone while the intra-prostatic concentration of DHT as well as of serum ADT-G and $3 \alpha$-diol-G are only reduced by 50-70\% (Fig. 4) (Labrie et al. 1985, Bélanger et al. 1986).

Completion of the identification and characterization of all the human UDP-glucuronosyl transferases has made possible the use of the glucuronide derivatives of androgens as markers of androgenic activity. In fact, UGT2B7, UGT2B15 and UGT2B17 are the three enzymes responsible for the glucuronidation of all androgens and their metabolites in the human (Bélanger et al. 2003). The relatively simple inactivation mechanisms of androgens 


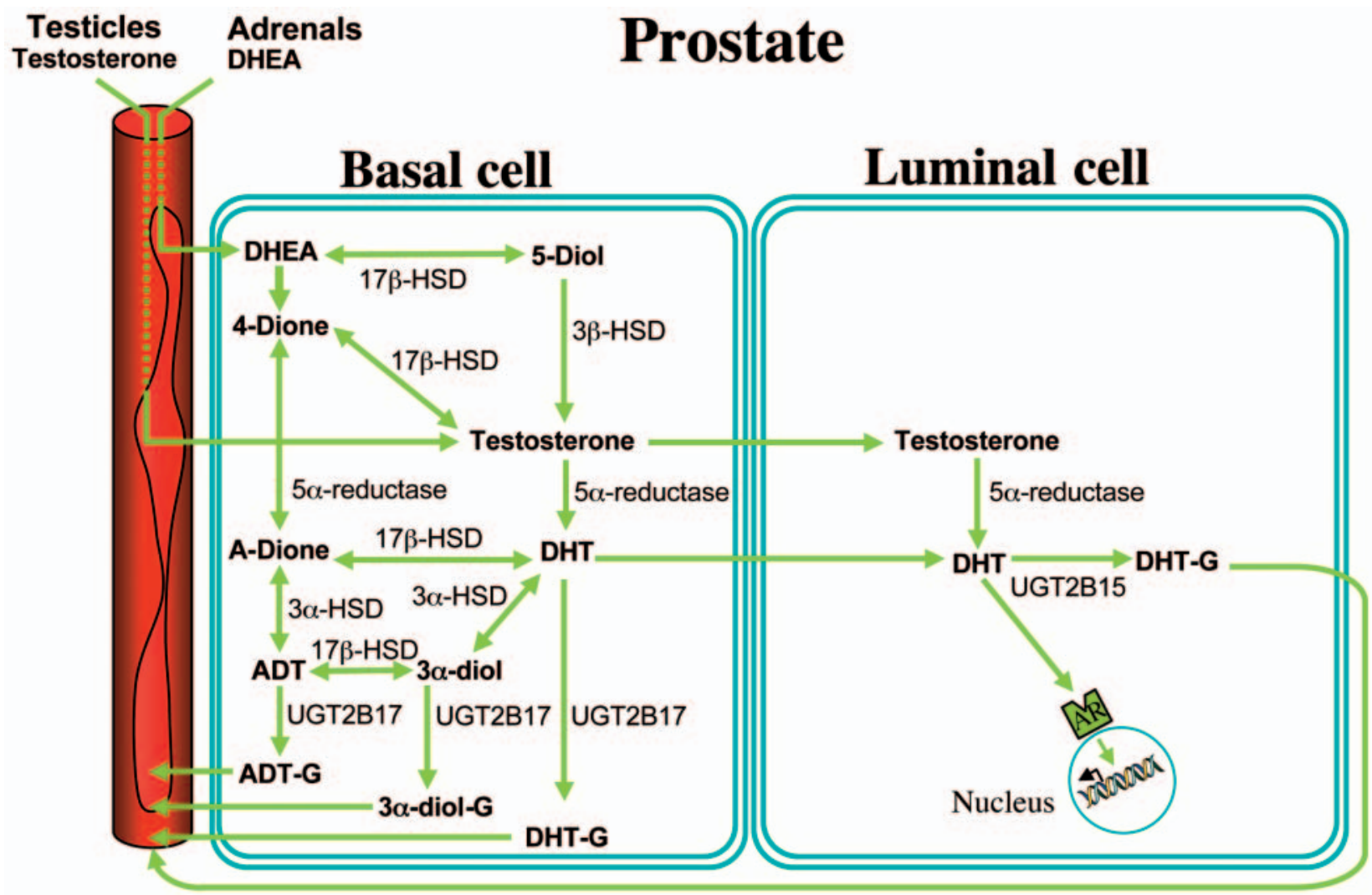

Figure 7 Distribution of the steroidogenic and steroid-metabolizing enzymes in the human prostate.

(Fig. 3) permits measurement of the sum of the metabolites of all androgens in the circulation, thus offering a precise assessment of the total androgenic activity in both women and men.

While the only means of determining androgenic activity in specific tissues is the direct measurement of the intra-tissular concentration of the active androgens, such measurements are not possible in the human except under exceptional circumstances such as in samples of cancer tissue obtained at surgery (Poortman et al. 1983, Labrie et al. 1985, Bélanger et al. 1989). However, while not permitting the assessment of androgenic activity in specific tissues, measurement by validated mass spectrometry techniques of the glucuronide derivatives of ADT and $3 \alpha$-diol permits an accurate assessment of total androgenic activity in the whole organism. In fact, since inactivation of the

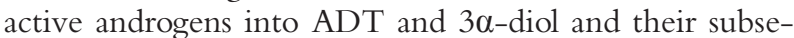
quent glucuronidation into ADT-G and $3 \alpha-$ diol-G is the obligatory route of elimination of androgens (Coffman et al. 1990, Beaulieu et al. 1996, 1997, Carrier et al. 2000, Turgeon et al. 2000) (Fig. 8), this approach appears to be the best means of evaluating total androgenic activity in individual subjects and patients. The clinician can then reliably correlate these values of androgenic activity with the other clinical findings.
As mentioned above, the level of transformation of the adrenal precursor steroid DHEA into androgens and/or estrogens in peripheral target tissues depends upon the level of expression of the various steroidogenic enzymes in each cell of each of these tissues (Labrie 1991, Labrie et al. $2003 a$ ). This situation of a high secretion rate of adrenal precursor sex steroids by the adrenals in men and women is thus completely different from all animal models used in the laboratory, namely rats, mice, guinea pigs and all others (except monkeys), where the secretion of sex steroids takes place exclusively in the gonads and the adrenals do not secrete significant amounts of DHEA (Bélanger et al. 1989).

The classical concept of androgen and estrogen secretion in women assumed that all sex steroids had to be transported by the general circulation following secretion by the ovaries before reaching the target tissues. According to this classical concept, it was erroneously believed that the active steroids could be measured directly in the circulation, thus providing a potentially valid measure of the general exposure of the whole body to sex steroids. In fact, this concept is valid only for animal species lower than primates but it does not apply to the human, especially in postmenopausal women where all estrogens and almost all androgens are made locally from DHEA in the peripheral tissues which possess the enzymes required to synthesize 


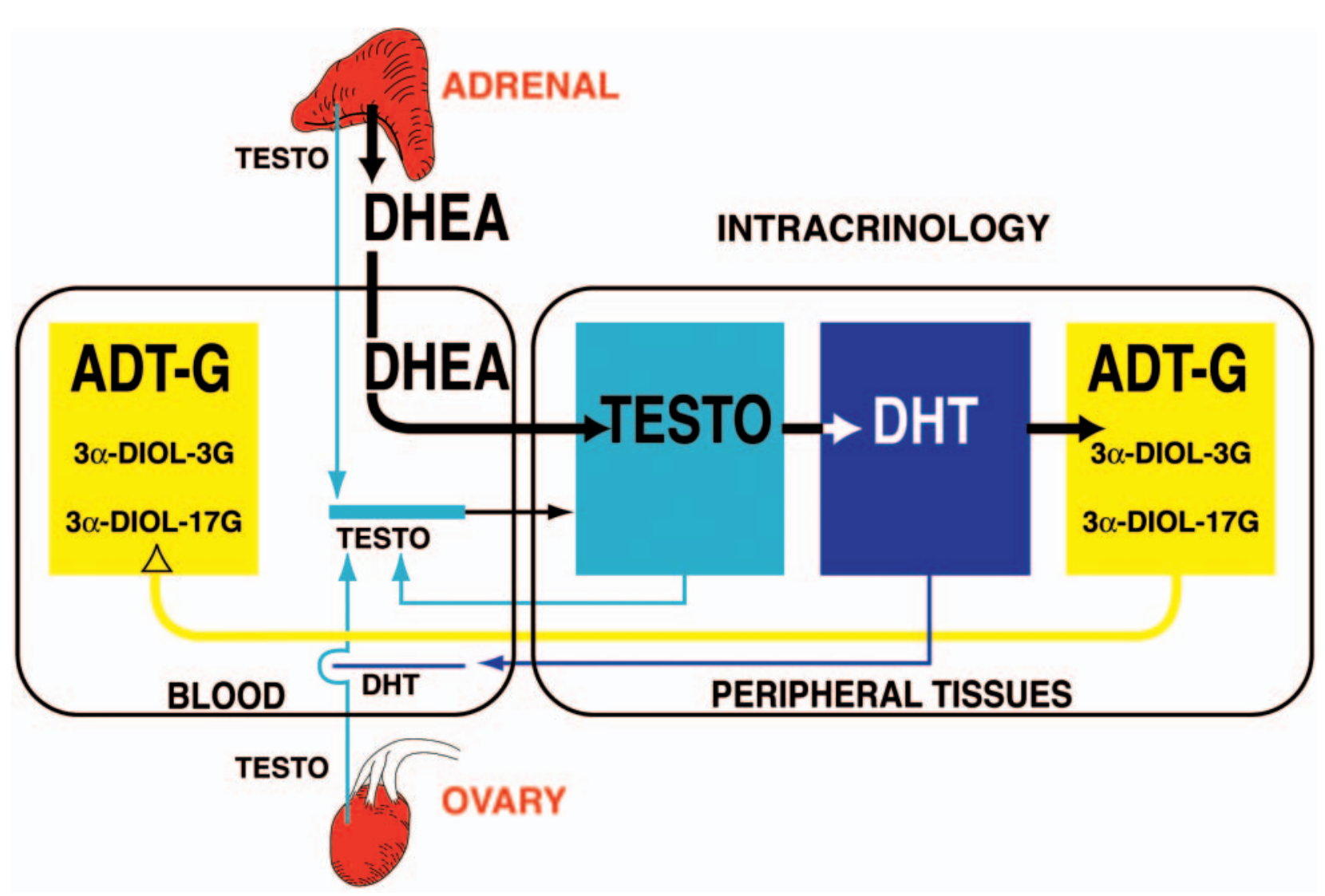

Figure 8 Schematic representation of the very important contribution of the precursor DHEA of adrenal origin to total androgenic activity in postmenopausal women with a parallel minor contribution of testosterone (TESTO) of ovarian and adrenal origins. By intracrine mechanisms, DHEA is transformed into testosterone and DHT in peripheral tissues and then into the inactive metabolites ADT and $3 \alpha$-diol

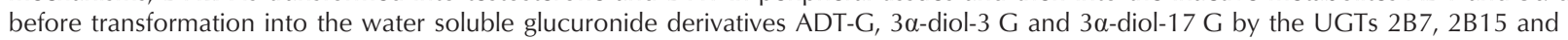
2B17. These water-soluble metabolites are then released into the general circulation where they can be measured. A very small proportion of the testosterone and DHT made intracellularly by the steroidogenic enzymes of the intracrine pathway diffuse into the circulation. The height of the colored boxes is proportional to the concentration of each steroid.

active sex steroids. Such a local biosynthesis and action of androgens in target tissues eliminates the exposure of other tissues to androgens and thus minimizes the risks of undesirable masculinizing or other androgen-related sideeffects. The same applies to estrogens, although we feel that a reliable parameter of total estrogen secretion (comparable with the glucuronides identified for androgens) has yet to be determined.

Today's knowledge of androgen physiology provides an explanation for the inconclusive studies on the role of androgens in women under various clinical conditions (Leiblum et al. 1983, Garland et al. 1992, Lipworth et al. 1996, Laughlin \& Barrett-Connor 2000, Couzinet et al. 2001, Davis \& Tran 2001, Labrie et al. 2003a, Miller et al. 2004, Tchernof \& Labrie 2004).

We feel that the increased understanding of androgen and estrogen formation and action in peripheral target tissues called intracrinology (Labrie 1991, Luu-The et al. 1995b, Labrie et al. 1997a,b,c,d), as well as our recent observations indicating the predominant role of androgens over that of estrogens in the prevention of bone loss after ovariectomy in the rat (Martel et al. 1998) and the observation of a similar situation in postmenopausal women (Labrie et al. 1997b), have paved the way for a timely and potentially highly significant progress in the field of sex steroid replacement therapy and aging. Such a possibility is well supported by our observations and those of others of a series of beneficial effects of DHEA in postmenopausal women (Morales et al. 1994, Diamond et al. 1996, Labrie et al. 1997b, Arlt et al. 1999, Baulieu et al. 2000).

Role of DHEA in bone physiology

A predominant role of androgens in bone physiology is well documented (Chesnut et al. 1983, Need et al. 1987, Savvas et al. 1988, Davis et al. 1995, Raisz et al. 1996, Labrie et al. 1997b, Martel et al. 1998, Baulieu et al. 2000, 
Miller et al. 2002). In fact, both testosterone and DHT increased the transcription of $\alpha(\mathrm{I})$ procollagen mRNA in osteoblast-like osteosarcoma cells (Benz et al. 1991). Treatment with DHT has also been shown to stimulate endochondral bone development in the orchiectomized rat (Kapur \& Reddi 1989). Bone mineral density measured in the lumbar spine, femoral trochanter and total body was increased more by estrogen plus testosterone implants than by $\mathrm{E}_{2}$ alone over a 24-month treatment period in postmenopausal women (Davis et al. 1995).

Moreover, in established osteoporosis, anabolic steroids have been reported to help prevent bone loss (Hennernan \& Wallach 1957). Similarly, subcutaneous $\mathrm{E}_{2}$ and testosterone implants have been found to be more efficient than oral estrogen in preventing osteoporosis in postmenopausal women (Savvas et al. 1988). Although the difference observed in that study has been attributed to the different routes of administration of the estrogen, the cause of the difference could well be the action of testosterone. As an index of increased bone formation, an increase in serum osteocalcin, a marker of bone formation, has been found in postmenopausal women receiving methyltestosterone plus estrogen, compared with estrogen alone (Raisz et al. 1996). Moreover, androgen therapy, as observed with nandrolone decanoate, has been found to increase vertebral bone mineral density in postmenopausal women (Need et al. 1989). Although androgens are gaining increasing support due to their unique actions in postmenopausal women, virilizing effects are observed with the use of testosterone (Burger et al. 1984, Studd et al. 1987).

In order to avoid the limitations of standard estrogen therapy (ERT) or hormone replacement therapy (HRT), we have studied the effect of DHEA administration to 60to 70 -year-old women for 12 months on bone mineral density, parameters of bone formation and turnover, serum lipids, glucose and insulin, adipose tissue mass, muscular mass, energy and well-being as well as on vaginal and endometrial histology (Diamond et al. 1996, Labrie et al. 1997b). DHEA was administered percutaneously to avoid first passage of the steroid precursor through the liver.

We have thus evaluated the effect of chronic replacement therapy with a $10 \%$ DHEA cream applied once daily for 12 months in 60- to 70-year-old women $(n=15)$. Anthropometric measurements showed no change in body weight but a $9 \cdot 8 \%$ decrease in subcutaneous skin fold thickness at 12 months $(P<0 \cdot 05)$ (Diamond et al. 1996). Bone mass density was increased by $2 \cdot 3 \%$ at the hip, $3.75 \%$ at the hip Ward's triangle and $2 \cdot 2 \%$ at the lumbar spine level (all $P<0 \cdot 05)$ (Labrie et al. 1997b). These changes in bone mineral density were accompanied by significant decreases at 12 months of $38 \%$ and $22 \%$ in urinary hydroxyproline and in plasma bone alkaline phosphatase respectively (all $P<0 \cdot 05$ ). An increase of $135 \%$ over control $(P<0.05)$ in plasma osteocalcin was concomitantly observed, thus suggesting a stimulatory effect of DHEA on bone formation.

\section{DHEA, abdominal obesity and the metabolic syndrome}

Abdominal obesity is associated with an increased risk of insulin resistance, type 2 diabetes and atherosclerosis, an association called the metabolic syndrome (Shimokata et al. 1989, Cefalu et al. 1995, Ferrannini et al. 1997, Kopelman 2000). Among other factors, hormonal changes, especially the declining secretion of DHEA and DHEA-S by the adrenals is thought to be a factor involved (Tchernof et al. 1996). In rat and mouse models, DHEA administration reduces visceral fat accumulation in diet-induced obesity (Yen et al. 1977, Cleary \& Zisk 1986, Mohan et al. 1990, Hansen et al. 1997). A beneficial effect of DHEA has also been observed on the decrease in insulin resistance that occurs with age (Han et al. 1998).

In a study performed in postmenopausal women who received a DHEA cream for 12 months, we found that insulin resistance was decreased while subcutaneous fat at the level of the thigh was also decreased (Diamond et al. 1996). Moreover, the daily administration of $50 \mathrm{mg}$ DHEA for 6 months in 65- to 78-year-old men and women decreased abdominal visceral fat by $10 \cdot 2 \%$ in women and $7 \cdot 4 \%$ in men (Villareal \& Holloszy 2004). In the same study, abdominal subcutaneous fat was decreased by $6 \%$ in both women and men. Moreover, the responsiveness of serum insulin to the glucose tolerance test was decreased by $13 \%$ with no change in the glucose response, thus leading to a $34 \%$ improvement in the insulin sensitivity index following DHEA administration. No change in serum prostate-specific antigen (PSA) was observed in men receiving DHEA. An improvement in DHEA action has also been found in middle-aged men suffering from hypercholesterolemia (Kawano et al. 2003).

In a previous study performed by the same group, DHEA administration for 6 months decreased total body fat mass by $1.4 \mathrm{~kg}$ while fat-free mass was increased by $0.9 \mathrm{~kg}$ (Villareal et al. 2000). No change of body composition was found in studies where DHEA was administered for only 3 months (Flynn et al. 1999, Jedrzejuk et al. 2003) or 4 months (Arlt et al. 2001).

\section{Effect of androgens on libido, hot flushes and quality of life}

Community-based studies suggest self-reported sexual dysfunctions in women that ranges from 8 to $50 \%$ (Laumann et al. 1999). It is believed that low serum free testosterone is the diagnostic marker of 'female androgen insufficiency' (Bachmann et al. 2002) as indicated in some studies (Sherwin \& Gelfand 1987, Davis et al. 1995, Shifren et al. 2000, Goldstat et al. 2003) and by expert opinions (Cameron \& Braunstein 2004). In fact, the incidence of low libido and sexual dysfunction increases with age in women from the third decade (Laumann et al. 1999) as well as after ovariectomy (Nathorst-Boos \& von Schoultz 1992). While phychosocial and health factors are involved in low arousal and low sexual desire 
(Dennerstein et al. 1997), it is believed that low androgens play an independent role (Bachmann et al. 2002, Miller et al. 2004).

In fact, androgens are known to play a role in women's arousability and pleasure as well as intensity and ease of orgasm. Androgens are also involved in the neurovascular smooth muscle response of swelling and increased lubrication (Basson 2004). It should be remembered that DHEA is transformed into both androgens and estrogens in the vagina (Sourla et al. 1998; Berger et al. 2005). Estrogens, on the other hand, affect the vulval and vaginal congestive responses. Since estrogens also affect mood, they have an influence on sexual interest (Basson 2004).

In a community-based cross-sectional study of 102118 to 75-year-old women, no clinically significant correlation was observed between a low score of any domain of the profile of female sexual function and low serum levels of free testosterone or 4-dione. However, an association was found between low DHEA-S and low sexual responsiveness in women aged $\geq 45$ years. There was also a significant correlation between low serum DHEA-S and low arousal, pleasure and orgasm. For women aged 18-44 years, a low domain score for sexual desire, sexual arousal and sexual responsiveness was associated with a serum DHEA-S below the 10th centile (Davis 2005).

Loss of libido and/or sexual satisfaction are common in early postmenopause. The addition of androgens to HRT is known to have beneficial effects on these problems (Greenblatt et al. 1950, Grody et al. 1953, Leiblum et al. 1983, Sherwin \& Gelfand 1987, Sherwin 1988). Shifren et al. (2000) have found that transdermal testosterone administered by patch improved sexual frequency, pleasure and mood in surgically menopausal women. The effect was seen at a daily $300 \mu \mathrm{g}$ dose of testosterone, a dose that led to serum testosterone levels in the upper limit of normal. Testosterone treatment has also been studied in non-androgen-deficient women complaining of decreased libido (Goldstat et al. 2003). Such treatment with testosterone improved libido and sexual function as well as quality of life compared with placebo. Similarly, in menopausal women with normal levels of androgens, the addition of methyltestosterone to estrogen increased sexual desire and frequency as compared with estrogen alone (Lobo et al. 2003). Similar results have been observed with testosterone implants (Davis et al. 1995). Among women with dysfunction of sexual interest and desire, androgen therapy has been suggested for those having free serum testosterone levels within the lower quantile of the reference range (Bachmann et al. 2002). In fact, there is increased use of testosterone to treat hypoactive sexual desire disorder (HSDD) (Sherwin \& Gelfand 1987, Davis et al. 1995, Shifren et al. 2000, Goldstat et al. 2003). A series of randomized clinical trials demonstrate that testosterone is effective in women with HSDD.

In addition, the detailed benefits of androgens added to ERT or HRT have been described on general well-being, energy, mood and general quality of life (Sherwin \& Gelfand 1985, Sherwin 1988). Improvements in the major psychologic and psychomatic symptoms, namely irritability, nervousness, memory and insomnia have been observed following addition of androgens to ERT (Notelovitz et al. 1991). It should also be mentioned that androgenic compounds have been found to be beneficial for the treatment of the mastalgia frequently caused by HRT (Pye et al. 1985). In fact, ERT may result in severe breast pain which may lead to discontinuation of therapy.

The androgenic effect of DHEA should also be useful in reducing hot flushes. In fact, androgen therapy is successful in reducing hot flushes in hypogonadal men (De Fazio et al. 1984). Moreover, the addition of androgens has been found to be effective in relieving hot flushes in women who had unsatisfactory results with estrogen alone (Sherwin \& Gelfand 1984). Hot flushes are one of the main reasons women initially seek HRT therapy, and estrogen is very effective at alleviating this symptom. Other studies have also shown a beneficial effect of DHEA on hot flushes (Baulieu 1999, Stomati et al. 2000).

A clear example of the nature of androgen deficiency of adrenal origin is provided by cases of adrenal insufficiency. Arlt et al. (1999) have studied the effect of $50 \mathrm{mg}$ DHEA daily and placebo for 4 months in a population of women suffering from adrenal insufficiency. Treatment with DHEA raised serum testosterone in the low normal range. Such treatment increased the frequency of sexual thoughts, interest and satisfaction. Well-being, depression and anxiety were also improved. In a study where DHEA was administered at a high $300 \mathrm{mg}$ daily dose, a greater subjective mental $(P<0 \cdot 016)$ and physical $(P<0 \cdot 030)$ stimulation was observed in response to an erotic video (Hackbert \& Heiman 2002). In a study performed in women receiving $50 \mathrm{mg}$ DHEA daily, improved libido was observed in women aged 70 years or more but not in those aged 60-70 years (Baulieu 1999).

\section{Additional potential benefits of DHEA}

The 70-95\% reduction in the formation of DHEA and DHEA-S by the adrenals during aging results in a dramatic reduction in the formation of androgens and estrogens in peripheral target tissues, which could well be involved in the pathogenesis of age-related diseases such as insulin resistance (Coleman et al. 1982, Schriock et al. 1988) and obesity (Nestler et al. 1988, MacEwen \& Kurzman 1991, Tchernof et al. 1995). Low circulating levels of DHEA-S and DHEA have also been found in patients with breast cancer (Zumoff et al. 1981) and DHEA has been found to exert anti-oncogenic activity in a series of animal models (Schwartz et al. 1986, Gordon et al. 1987, Li et al. 1993). DHEA has also been shown to have immunomodulatory effects in vitro (Suzuki et al. 1991) and in vivo in fungal and viral diseases (Rasmussen et al. 1992), including HIV (Henderson et al. 1992). On the other hand, a stimulatory 
effect of DHEA on the immune system has been described in postmenopausal women (Casson et al. 1993).

DHEA has been shown to have important effects on the skin of aged individuals, the most salient of which is an increase in sebum production (Labrie et al. 1997b). The index of sebum secretion was 79\% increased after 12 months of DHEA therapy with a return to pretreatment values 3 months after cessation of treatment. This has been shown in a number of studies performed in women, particularly those $>70$ years old who are physiologically hyposeborrheic and thus found an improvement in their skin with DHEA administration. The DHEA-induced increase in sebum production observed in our study is probably due to the fact that the sebaceous glands contain all the steroidogenic enzymes necessary to catalyze the transformation of DHEA into the androgen DHT, and that this androgen is the main stimulator of sebaceous gland activity (Labrie et al. 2000a, 2003a).

Apart from sebum production, other beneficial effects of DHEA on the skin have been noticed. To date, evaluation of the dermatological aspects of DHEA administration have only been performed in some detail in one study, the DHEA study in which male and female subjects between the ages of 60 and 79 years were orally administered $50 \mathrm{mg}$ DHEA, once daily for 1 year. In that study, Baulieu et al. (2000) evaluated skin hydration, skin pigmentation and skin thickness. Skin surface hydratation significantly increased for the whole DHEA-treated population examined after 12 months of treatment. Skin surface hydratation is considered a real benefit for the skin, especially in aged individuals since in these subjects the dryness makes the skin rough. DHEA also significantly decreased facial skin pigmentation (yellowness) for the whole population. This decrease was more pronounced in women $>70$ years who are more concerned by age-related pigment changes. The two other components of skin colour remained stable during the duration of the study (i.e. lightness and redness).

Measurements of mid-thigh fat and muscle areas by computed tomography have shown a $3.8 \%$ decrease $(P<0 \cdot 05)$ in femoral fat and a $3.5 \%$ increase $(P<0 \cdot 05)$ in femoral muscular area at 12 months (Diamond et al. 1996). There was no significant change in abdominal fat measurements. These changes in body fat and muscular surface areas were associated with a $12 \%$ decrease $(P<0 \cdot 05)$ of fasting plasma glucose and a $17 \%$ decrease $(P<0.05)$ in fasting plasma insulin levels. Treatment with DHEA had no undesirable effect on the lipid or lipoprotein profile. In fact, there was an overall trend for a 3-10\% decrease in total cholesterol and its lipoprotein fractions. Plasma triglycerides were not affected.

DHEA administration stimulated vaginal epithelium maturation in eight out of ten women who had a maturation value of zero at the onset of therapy while a stimulation was also seen in the three women who had an intermediate vaginal maturation before therapy. Most importantly, the estrogenic stimulatory effect observed in the vagina was not found in the endometrium which remained completely atrophic in all women after 12 months of DHEA treatment (Labrie et al. 1997b).

The present data suggest that the beneficial effects of DHEA therapy in postmenopausal women are exerted through the transformation of the steroid precursor into androgens and/or estrogens in specific intracrine target tissues, thus limiting the possibility of side-effects. As an example, the absence of stimulation of the endometrium by DHEA (Labrie et al. 1997c, Baulieu et al. 2000) should eliminate the need for progestin replacement therapy, thus avoiding the fear of progestin-induced breast cancer in postmenopausal women (Women's Health Initiative 2002). The observed stimulatory effect of DHEA on bone mineral density and the increase in serum osteocalcin, a marker of bone formation, are of particular interest for the prevention and treatment of osteoporosis and indicate a unique activity of DHEA on bone physiology, namely a stimulation of bone formation, while ERT and HRT can only reduce the rate of bone loss. In the light of the Women's Health Initiative study, the indication and benefits of HRT should be evaluated with care and adapted to the clinical situation of each woman.

The effects of DHEA are a combination of estrogen-like and androgenic effects

Androgen therapy, as observed with nandrolone decanoate, has been found to increase vertebral bone mineral density as well as cortical bone mineral content in postmenopausal women (Need et al. 1989). Androgenic sideeffects, however, were recorded in 50\% of patients. Such data are of interest since while almost all present therapies are limited to a reduction of bone loss, an increase in bone mass was found with the use of the anabolic steroid nandrolone. A similar stimulation of bone formation by androgens has been suggested in a hypogonadal male (Baran et al. 1978). A stimulation of bone formation in postmenopausal women treated with DHEA for 12 months is reported by Labrie et al. (1997b).

Most importantly, it has been observed that androgens exert a direct anti-proliferative activity on the growth of ZR-75-1 human breast cancer cells in vitro and that such an inhibitory effect of androgens is additive to that of an anti-estrogen (Poulin \& Labrie 1986, Poulin et al. 1988). Similar inhibitory effects have been observed in vivo on ZR-75-1 xenographs in nude mice (Dauvois et al. 1991). Androgens have also been shown to inhibit the growth of 7,12-dimethylbenz(a)anthracene-induced mammary carcinoma in the rat, this inhibition being reversed by the simultaneous administration of the pure anti-androgen flutamide (Dauvois et al. 1989). Taken together, these data indicate the involvement of the androgen receptor in the inhibitory action of DHEA on breast cancer. 
DHEA

$\downarrow$ CANCER

MAMMARY GLAND

个 VAGINAL EPITHELIUM

NO EFFECT

ON ENDOMETRIUM

$\uparrow$ BONE FORMATION

$\downarrow$ INSULIN

$\downarrow$ GLUCOSE

$\uparrow$ MUSCLE MASS

$\downarrow$ FAT TISSUE

$\uparrow$ WELL BEING

Etc.

\section{ERT}

MAMMARY GLAND

CHOLESTEROL

TRIGLYCERIDES

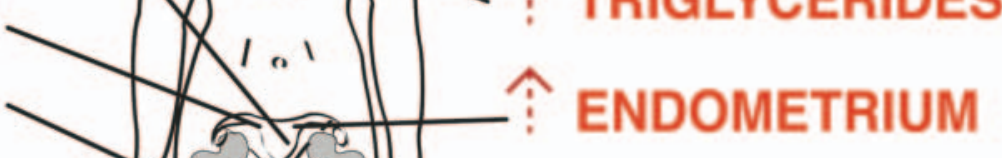

Figure 9 Comparison of the effects of standard ERT (estrogen) and DHEA on parameters of menopause.

Since the endometrium remained atrophic after 12 months of treatment of postmenopausal women with DHEA (Labrie et al. 1997b), the proposed novel approach with DHEA (Fig. 9) should eliminate the need to use a progestin to protect against endometrial proliferation, thus avoiding the recently demonstrated stimulatory effect of progestins on breast cancer (Bergkvist et al. 1989, Clarke \& Sutherland 1990, Musgrove et al. 1991, Horwitz 1992, Colditz et al. 1995, Magnusson et al. 1999, Persson 1999, Ross et al. 2000, Women's Health Initiative 2002).

The potential approach of HRT with DHEA is based upon the recent progress achieved in our understanding of sex steroid physiology in women and the recognition that women, at menopause, are not only deprived of estrogen due to the arrest of estrogen secretion by the ovaries, but have already been submitted for a few years to a decreasing exposure to androgens. In fact, normal women produce an amount of androgens equivalent to two-thirds of the androgens secreted in men (Labrie et al. 1997a). The pool of androgens in women decreases progressively from the age of 30 years in parallel with the decrease in the serum concentration of DHEA and DHEA-S (Labrie et al. 1997c). Consequently, it appears logical to use both androgenic and estrogenic replacement therapy at peri- and postmenopause, thus maintaining a physiological balance between these two classes of sex steroids in each cell and tissue, a goal which can only be met by the local formation of androgens and estrogens in peripheral tissues from a steroid precursor such as DHEA (Fig. 9). In Fig. 9, comparison is made with the positive and negative effects of DHEA versus classical ERT.

It should also be mentioned that our data obtained in the rat clearly demonstrated that DHEA can provide beneficial effects which are lacking with the use of a SERM alone (Labrie et al. 2003b). In fact, while a SERM has effects limited to inhibition of bone resorption, the addition of DHEA stimulates bone formation (an effect not found with a SERM or an estrogen) and further reduces bone resorption above the effect achieved with a SERM alone. In addition to an increase in bone formation, DHEA has also been shown in postmenopausal women to stimulate vaginal maturation and decrease skin dryness.

\section{Role of DHEA in men}

Prostate cancer is the most frequently diagnosed cancer and the second cause of cancer death in men in North America (Jemal et al. 2005). In fact, one in eight men will 
be diagnosed with prostate cancer during his lifetime. At the present rate, of the male population living in the USA, prostate cancer will kill more than 3 million men. Prostate cancer is thus a major medicosocial problem comparable with that of breast cancer in women. In fact, it was predicted that 30350 men will die from prostate cancer in the USA in 2005.

The serious and frequently lethal cardio- and cerebrovascular complications of estrogens (VACURG 1967, Robinson \& Thomas 1971, Peeling 1989), on one hand, and the psychological (Lunglmayr et al. 1988, Cassileth et al. 1989) as well as the physical limitations of orchiectomy, on the other hand, have generally delayed endocrine treatment until late stages of the disease when pain and debility had developed. Typically, at such a late stage, the large and disseminated tumors show poor and shortlived responses, thus limiting the success of endocrine therapy. In fact, similar to treatments for all other types of cancers, androgen blockade loses its effectiveness with increasing size of the tumors (Chen et al. 1996).

As indicated by a high proportion of positive responses achieved after only partial blockade of androgens by orchiectomy (Nesbit \& Baum 1950, Staubitz et al. 1954, VACURG 1967, Mettlin et al. 1982, Murphy et al. 1983), prostate cancer is the most sensitive of all hormonesensitive cancers to endocrine therapy. This uniquely high sensitivity of prostate cancer to androgens should be exploited optimally in order to best succeed in the fight against this disease.

In the course of our attempts to find an explanation for the lack of a stimulatory effect of chronic administration of $\mathrm{GnRH}$ agonists on gonadal functions, we made the unexpected observation that treatment of adult male rats for a few days led to variable degrees of inhibition of serum testosterone levels accompanied by a relatively small but usually significant inhibition of ventral prostate, seminal vesicle and testis weight (Auclair et al. 1977a,b). It should be mentioned that when we were treating rats with a GnRH agonist some 28 years ago we were expecting to observe larger seminal vesicles and a prostate of increased volume. Most unexpectedly, the opposite observation was made: the prostate, the seminal vesicles and the testicles became smaller instead of larger after a few days of treatment with a GnRH superagonist.

While experiments performed in the rat were simply suggestive of an inhibitory effect of $\mathrm{GnRH}$ agonists on testicular functions, we discovered in 1979 at our Clinic at the Laval University Medical Center that medical castration is achieved in men following chronic administration of GnRH agonists (Labrie et al. 1980).

Soon after our observation (Labrie et al. 1980) that administration of the GnRH agonist buserelin led to an almost complete inhibition of serum testosterone and DHT levels within 2 weeks following administration by the intranasal route, a less than optimal route of administration (Labrie et al. 1980), a detailed comparison of the effect of various doses of the same $\mathrm{GnRH}$ agonist was performed after administration by the intranasal and subcutaneous routes (Faure et al. 1982). It is well recognized that medical castration with a $\mathrm{GnRH}$ agonist is equivalent to orchiectomy for prostate cancer therapy (Prostate Cancer Triallists' Collaborative Group 2000). In a comparison of 11 trials in which a GnRH agonist was used and in 17 trials in which orchiectomy was used, no difference was seen in the response or survival rate (Prostate Cancer Triallists' Collaborative Group 2000).

Two equally important sources of androgens are present in men

An important advance in our understanding of the biology and endocrinology of prostate cancer and its major impact on cancer treatment is the observation that humans and some other primates are unique among animal species in having adrenals that secrete large amounts of the inactive precursor steroids DHEA, its sulfate DHEA-S and some 4-dione, which are converted into potent androgens in a large series of peripheral tissues, including the prostate (Fig. 1B).

As indicated above, the local synthesis of active steroids in peripheral target tissues has been named intracrinology (Labrie et al. 1988, 2003a, Labrie 1991). The active androgens made locally in the prostate exert their action by interacting with the androgen receptor in the same cells where their synthesis takes place without being released in significant amounts in the extracellular environment or the general circulation. Contrary to the previous belief that the testes are responsible for $90-95 \%$ of total androgen production in men (as could be inferred from the 90-95\% decrease in serum testosterone observed after castration), it is now well demonstrated that the prostatic tissue efficiently transforms the inactive steroid precursors DHEA-S, DHEA and 4-dione into the active androgens testosterone and DHT locally in peripheral tissues, including the prostate, without significant release of the active androgens in the circulation. In fact, the prostate makes its own androgens at a level comparable with the androgens of testicular origin (Fig. 1B).

\section{Combined androgen blockade (CAB) in advanced disease}

The first treatment shown to prolong life in prostate cancer was the combination of a GnRH agonist to block androgen secretion by the testes in association with an effective dose of a pure anti-androgen such as flutamide, nilutamide or bicalutamide (Labrie et al. 1982, 1985). These anti-androgens (sometimes called non-steroidal anti-androgens) block the action of the androgens produced locally in the prostate by interfering at the level of the androgen receptor.

An interesting observation is that the first demonstration of the benefits of CAB on survival (Labrie et al. 1982, 1985) has been achieved in the most difficult group of 


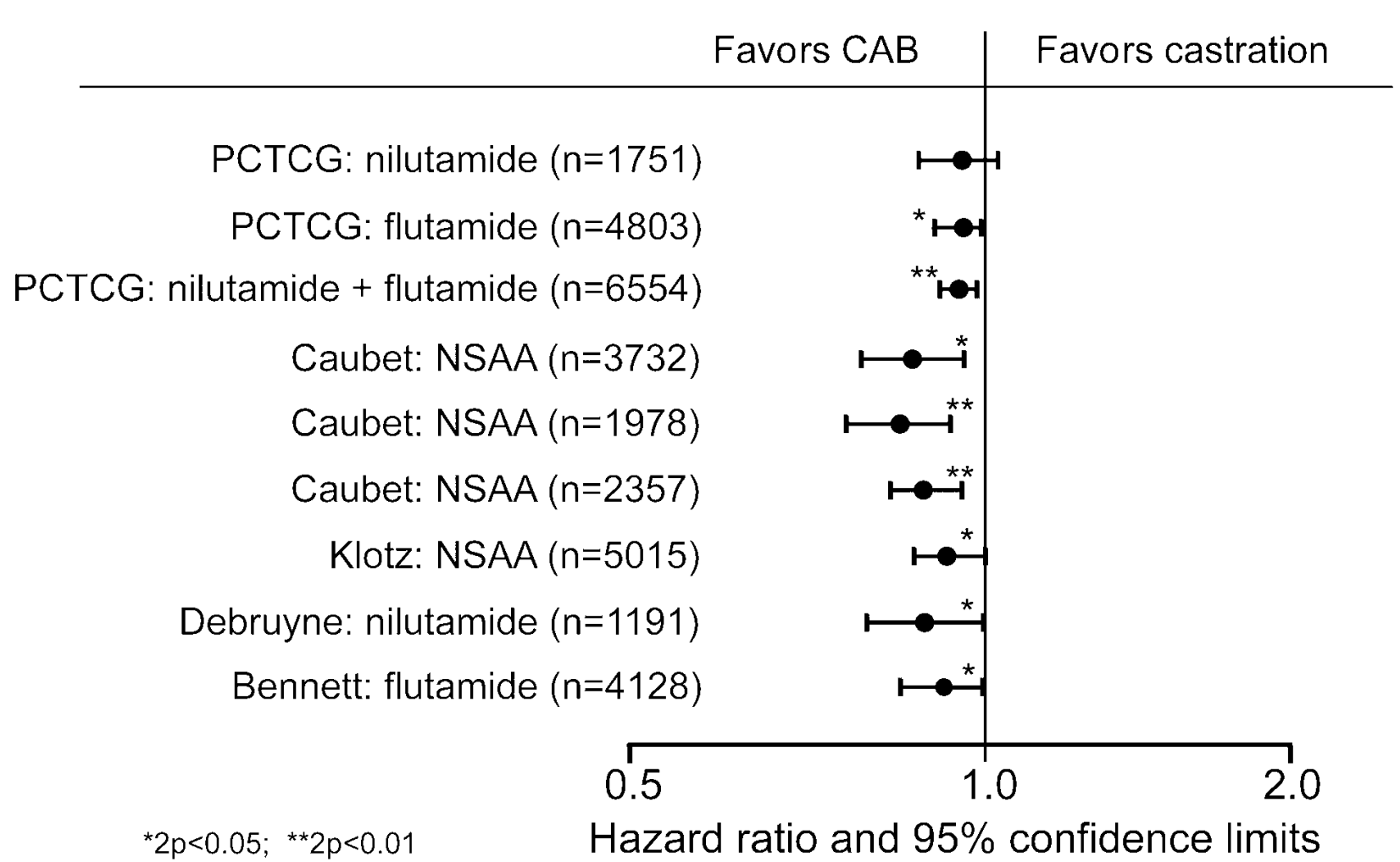

Figure 10 Summary of meta-analyses comparing CAB (combination of medical or surgical castration) associated with a pure anti-androgen or non-steroidal anti-androgen (NSAA), namely flutamide or nilutamide versus medical or surgical castration alone. Adapted from Klotz et al. (2001). Caubet=Caubet et al. (1997); Debruyne=Debruyne et al. (2001); Bennett=Bennett et al. (1999).

patients to treat, namely those suffering from metastatic or advanced disease. These data have been obtained with flutamide and nilutamide. Although, in principle, the clinical results should be similar for bicalutamide, the two anti-androgens flutamide and nilutamide are those first demonstrated in prospective and randomized studies to prolong life, to increase the number of complete and partial responses, to delay progression and to provide better pain control (thus improving quality of life) in metastatic prostate cancer when added to surgical or medical castration compared with castration alone (Crawford et al. 1989, Denis et al. 1993, 1998, Janknegt et al. 1993, Caubet et al. 1997, Dijkman et al. 1997, Bennett et al. 1999, Prostate Cancer Triallists' Collaborative Group 2000, Debruyne et al. 2001, Klotz 2001, 2003, Schmitt et al. 2001, Aprikian et al. 2003). In the first large scale randomized study, patients who were treated with flutamide and the GnRH agonist lupron lived, on average, $7 \cdot 3$ months longer than those who received lupron plus placebo (Crawford et al. 1989).

Analysis of all the studies performed with flutamide and nilutamide associated with medical or surgical castration compared with castration plus placebo shows that overall survival (deaths from all causes) is increased by an average of 3-6 months following the addition of a pure anti- androgen (Crawford et al. 1989, Denis et al. 1993, 1998, Janknegt et al. 1993, Caubet et al. 1997, Dijkman et al. 1997, Bennett et al. 1999, Prostate Cancer Triallists' Collaborative Group 2000, Schmitt et al. 2001) (Fig. 10). Since about $50 \%$ of patients in that age group (65 to 80 years old) die from causes other than prostate cancer, this 3-6 month difference in overall survival corresponds to an average of 6-12 months of life gained when cancerspecific survival is calculated. These additional months, or sometimes years, of life are obtained by simply adding a pure anti-androgen (flutamide, nilutamide or bicalutamide at a proper dose) to castration. Considering that such statistically significant benefits on survival are obtained, even at the very advanced stage of metastatic disease, these data demonstrate, as mentioned earlier, the particularly high level of sensitivity of prostate cancer to androgen deprivation.

As illustrated in Fig. 10, all the meta-analyses of all the data have shown significant $(2 P<0 \cdot 05)$ or highly significant $(2 P<0 \cdot 01)$ advantages of $\mathrm{CAB}$ versus castration alone in advanced prostate cancer (Caubet et al. 1997, Bennett et al. 1999, Prostate Cancer Triallists' Collaborative Group 2000, Debruyne et al. 2001, Klotz 2001, Schmitt et al. 2001). However, when the studies providing the most rigorous data are analyzed (Caubet et al. 1997), a 20\% 
advantage in overall survival is observed. Moreover, these differences are not those obtained strictly when comparing $\mathrm{CAB}$ versus castration but they rather compare immediate versus deferred $\mathrm{CAB}$ since most patients received an anti-androgen at the time of progression with castration alone.

It is of interest to mention the first results of a Japanese study (Akaza et al. 2004) showing improved PSA normalization $(79 \cdot 4 \%$ versus $38 \cdot 6 \%)$ at 12 weeks and time to treatment failure $(96 \cdot 1$ versus $67 \cdot 7$ weeks) in advanced prostate cancer patients who received the combination of a GnRH agonist and $80 \mathrm{mg} /$ day bicalutamide versus the GnRH agonist and placebo. The risk of progression during follow-up was thus reduced by $54 \%$ in the $\mathrm{CAB}$ group compared with chemotherapy. This study, however, is not sufficiently mature to calculate the effect on survival but the early effects observed are in line with previous studies.

Concerning the costs of treatment, as recently published by Aprikian et al. (2003), the cost per month of prolonged survival in prostate cancer achieved with the simple addition of a non-steroidal anti-androgen to castration (GnRH agonist or orchiectomy) is $50 \%$ of that of vinorelbine for lung cancer, $10 \%$ of the cost of renotecan for colon cancer and $10 \%$ of the cost of trastuzumab for breast cancer. Moreover, the non-steroidal anti-androgens have minimal toxicity while vinorelbine and irinotecan are associated with severe grade 3 and 4 clinical toxicities and trastuzumab has cardiac side-effects when associated with anthracyclines. As Klotz (2003) said, 'We should embrace the modest survival benefit of $\mathrm{CAB}$ in advanced prostate cancer and offer it to the appropriate patients.'

In addition to the prolongation of survival, all the studies have shown that the decrease in bone pain is more rapid and more complete and that progression of the cancer is delayed, thus improving quality of life, when $C A B$ is used compared with monotherapy. Moreover, $\mathrm{CAB}$ is the only treatment shown to prolong life in advanced disease. There is thus no other choice if one wants to prolong life. It should also be realized that there is no treatment of similarly advanced cancers that provides 3-6 months of prolongation of life or 6-12 months of additional cancerspecific survival with such a good quality of life. To the living population of males in the USA, where 3 million are expected to die from prostate cancer, 6 additional months of life correspond to the addition of 1.5 million years of life, while 12 additional months correspond to $3 \cdot 0$ million years of life.

\section{High probability of cure of localized prostate cancer by} treatment with $C A B$

Despite the important advance observed with monotherapy (GnRH agonists) in localized prostate cancer, namely at least a one-third reduction in deaths from prostate cancer (Peto \& Dalesio 2003), can we achieve better results?
Based upon the observation that $50 \%$ of androgens are left in the prostate after castration alone (Figs 1B and 4), it is reasonable to suggest that superior results can be achieved with the combination of a GnRH agonist and a pure anti-androgen. There are already data indicating that patients with minimal metastatic disease derive greater benefits than those with extensive metastatic disease (Crawford et al. 1989, Denis et al. 1998, Soloway 1998).

Using $\mathrm{CAB}$ in localized and locally advanced disease, the evidence obtained even indicates that long-term control or cure of the disease can be obtained in at least $90 \%$ of patients (Labrie et al. 2002). In fact, while almost all studies performed so far in localized prostate cancer have used monotherapy (medical or surgical castration) (Bolla et al. 1997, Pilepich et al. 1997, Granfors et al. 1998, Messing et al. 1999, Hanks et al. 2000, D'Amico et al. 2004), there are strong scientific reasons to believe that even much better results can be expected with $\mathrm{CAB}$ (Labrie et al. 1985, Caubet et al. 1997, Bennett et al. 1999, Labrie 2000a, b, Prostate Cancer Triallists' Collaborative Group 2000).

Since we have already obtained evidence for the high efficacy of long-term and continuous $\mathrm{CAB}$ in localized prostate cancer (Labrie et al. 1999a), it was felt important to examine the long-term outcome of these patients as assessed by biochemical failure (PSA progression) following cessation of continuous $\mathrm{CAB}$ previously administered for periods up to 11.3 years. The effect of $\mathrm{CAB}$ on long-term control or possible cure of prostate cancer was thus evaluated by the absence of biochemical failure or the absence of a PSA rise for at least 5 years following cessation of continuous treatment. A total of 57 patients with initial localized or locally advanced disease thus received $\mathrm{CAB}$ for periods ranging from 1 to 11 years. $\mathrm{CAB}$ was then discontinued and the patients followed for a minimum of 5 years. Among the 20 patients with stage T2-T3 cancer initially who stopped treatment after continuous $\mathrm{CAB}$ for more than 6.5 years, only two PSA rises occurred for a non-failure rate of $90 \%$ (Fig. 11). For the 11 patients who had received $\mathrm{CAB}$ for $3.5-6.5$ years, the non-failure rate was only $36 \%$. It is of major interest that serum PSA increased within 1 year after cessation of $\mathrm{CAB}$ in all 11 patients with stage $\mathrm{B} 2 / \mathrm{T} 2$ cancer initially treated with $\mathrm{CAB}$ for only 1 year, thus showing that active cancer remained present after short-term androgen blockade limited to 1 year despite undetectable PSA levels. Most importantly, in all patients who had biochemical failure after stopping $\mathrm{CAB}$, serum PSA rapidly decreased again to undetectable levels soon after CAB was restarted and PSA remained at such low levels afterward. Of these 57 patients, only one patient had died of prostate cancer at the last follow-up (Labrie et al. 2002).

These are remarkable results observed in patients with localized prostate cancer. Treatment, however, must be continuous, without interruption and should last for many years. It is important to mention that the major survival 


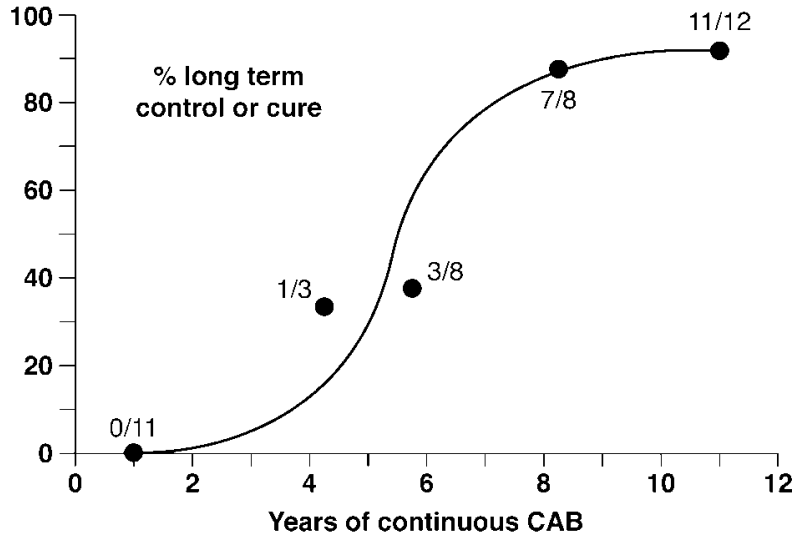

Figure 11 Effect of treatment duration of localized prostate cancer with continuous $\mathrm{CAB}$ on the probability of long-term control or cure of the disease as determined by no recurrence of a rise in PSA for at least 5 years after CAB cessation. The point at 4.75 years of treatment $(33 \%)$ refers to three patients treated with $\mathrm{CAB}$ for $3 \cdot 5-5 \cdot 0$ years and followed-up for at least 5 years, the point at 5.75 years refers to eight patients treated continuously with $C A B$ for $5 \cdot 0-6 \cdot 5$ years before cessation of treatment, the point at 8.25 years refers to eight patients treated continuously for $6 \cdot 5-9 \cdot 0$ years and the point at 11 years refers to 12 patients treated for $10-11 \cdot 7$ years with continuous $\mathrm{CAB}$ before stopping treatment. All patients were followed-up for at least 5 years after continuous $C A B$ or until a rise in PSA. Only one patient died of prostate cancer and 18 have died of other causes (Labrie et al. 2002).

benefits observed following androgen blockade, even in localized or locally advanced disease, are always associated with long-term (many years of non-interrupted) treatment (Bolla et al. 1997, Labrie et al. 1999b, 2002, Messing et al. 1999). In fact, an important observation is that when PSA increases following cessation of treatment, administration of $\mathrm{CAB}$ was successful in all cases in decreasing PSA to undetectable levels again, thus showing that, even after a long duration of treatment, resistance to $\mathrm{CAB}$ had not developed. In fact, resistance to $\mathrm{CAB}$ is the common finding in prostate cancer metastasized to the bone while it does not occur for the cancer localized in the prostate or in the prostatic area.

The present results obtained in prostate cancer patients diagnosed with localized disease and treated continuously for many years with $\mathrm{CAB}$ are not too different from the results that we have recently obtained with human breast tumor xenografts in nude mice where complete estrogen blockade achieved with a highly potent anti-estrogen led to the disappearance or cure of the tumors in $61 \%$ of cases within a few months (Roy et al. 2003). In fact, in both breast and prostate cancer, when the estrogens in breast cancer and the androgens in prostate cancer are blocked efficiently, cure of the disease can be achieved with hormonal therapy.

As mentioned above, however, the success of therapy requires long-term and continuous treatment before complete apoptosis or total cell death is achieved. Such results clearly indicate that intermittent androgen blockade should remain experimental and should not be used outside clinical trials. Breast and prostate cancers have many characteristics in common and much can be learned from looking at the results obtained in each of them. In fact, when we consider the biology of these two cancers, there are many common features, especially the high level of sensitivity to hormones.

Most importantly, the present data indicate that possible cure of the disease can be obtained in most patients with localized prostate cancer treated continuously with $\mathrm{CAB}$ for more than 8 years, thus raising hopes for the successful treatment of patients who fail after surgery, radiotherapy or brachytherapy where no or minimally effective alternative therapeutic approach exists.

Major impact of blockade of androgens derived from DHEA in prostate cancer

The life-saving benefits of androgen blockade in prostate cancer have been largely underestimated. When compared with other cancer therapies, the results obtained are quite remarkable. In agreement with the data summarized above, a recent analysis of all clinical trial data attributes part of the improving outlook in the field of prostate cancer to early detection and prompt radical prostatectomy, but mostly gives the credit to follow-up hormone therapy. 'Hormonal treatment as a whole works ridiculously well' (Peto \& Dalesio 2003), as reported by Arnst (2003). In fact, while death rates decreased by $1 \cdot 1 \%$ per year from 1993 to 2001 for all cancers combined, prostate cancer showed a larger decrease at 3.6\% (Mehring 2004). Although improvements in surgery and radiotherapy are likely to play a role, a study by Frank R Lichtenberg using National Cancer Institute data obtained from $2 \cdot 1$ million cancer patients has concluded that cancer-fighting drugs improved survival rates, especially for cancer of the prostate, where drug innovations have been the greatest (Mehring 2004).

It is important to note that androgen blockade is not only cytostatic, as was previously believed. In fact, androgen blockade is also cytotoxic or tumoricidal in localized disease. Moreover, it is important to remember that resistance to androgen blockade does not occur or is extremely rare in localized disease under treatment with CAB. Clearly, resistance to androgen blockade is a phenomenon typical of metastatic disease in the bones where the environment is very different and where the growth factors present in large amounts stimulate cancer growth, even in the absence of androgens. This knowledge about the absence of development of resistance to $\mathrm{CAB}$ in localized prostate cancer is extremely important. In fact, it is often erroneously believed that early androgen blockade should not be administered because resistance to treatment will develop and one might as well wait to use androgen blockade at a later stage of the disease. In fact, deferring 
treatment implies that very often it will then be too late because, following migration of the cancer to the bones, resistance to treatment will occur automatically. It should be realized that when prostate cancer is first detected, even by screening, the cancer is not small since its diameter is of the order of $1 \mathrm{~cm}$ or more. This is the most appropriate time to treat with the very strong hope of a cure. The results summarized above indicate that androgen blockade, more specifically $\mathrm{CAB}$, is probably the most efficient treatment of localized prostate cancer but the start of treatment should not be delayed.

It is important to remember that by avoiding the psychological limitations of surgical castration and the serious side-effects of high doses of estrogens, GnRH agonists are playing a leader role in the very efficient fight against prostate cancer. With the presently available techniques, screening can diagnose prostate cancer at a clinically localized stage in $99 \%$ of cases (Labrie et al. 1996a, 2002). Such an early diagnosis permits immediate treatment with a curative intent, $\mathrm{CAB}$ being a truly efficient alternative. Most importantly, CAB must be used immediately in patients who fail radical prostatectomy, radiotherapy or brachytherapy. Using this strategy, based upon today's available diagnostic and therapeutic approaches, death from prostate cancer can already be an exception (Labrie 2002).

\section{Acknowledgements}

The basic research on intracrinology was supported by the Canadian Instiutes of Health Research.

\section{References}

Adams JB 1985 Control of secretion and the function of C19- $\Delta^{5}$ steroids of the human adrenal gland. Molecular and Cellular Endocrinology 41 1-17.

Adamski J, Normand T, Leenders F, Monté D, Begue A, Stehelin D, Jungblut PW \& de Launoit Y 1995 Molecular cloning of a novel widely expressed human $80 \mathrm{kDa} 17 \beta$-hydroxysteroid dehydrogenase IV. Biochemical Journal 311 437-443.

Akaza H, Yamaguchi A, Matsuda T, Igawa M, Kumon H, Soeda A, Arai Y, Usami M, Naito S, Kanetake H et al. 2004 Superior anti-tumor efficacy of bicalutamide $80 \mathrm{mg}$ in combination with a luteinizing hormone-releasing hormone $(\mathrm{LHRH})$ agonist versus LHRH agonist monotherapy as first-line treatment for advanced prostate cancer: interim results of a randomized study in Japanese patients. Japanese Journal of Clinical Oncology 34 20-28.

Andersson S 2001 Steroidogenic enzymes in skin. European Journal of Dermatology $11293-295$.

Andersson S \& Russel DW 1990 Structural and biochemical properties of cloned and expressed human and rat steroid $5 \alpha$-reductases. PNAS 87 3640-3644.

Andersson S, Bergman DM, Jenkins EP \& Russel DW 1991 Deletion of steroid $5 \alpha$-reductase 2 gene in male pseudophermaphroditism. Nature 354 159-161.

Andersson S, Geissler WM, Patel S \& Wu L 1995 The molecular biology of androgenic $17 \beta$-hydroxysteroid dehydrogenases. Journal of Steroid Biochemistry and Molecular Biology 53 37-39.
Anonymous 2004 Stat bite: Trends in cancer mortality by primary cancer site, 1992-2001. Journal of the National Cancer Institute 96 987.

Aprikian AG, Fleshner N, Langleben A \& Hames J 2003 An oncology perspective on the benefits and cost of combined androgen blockade in advanced prostate cancer. Canadian Journal of Urology 10 1986-1994.

Archer DF, Furst K, Tipping D, Dain MP \& Vandepol C 1999 A randomized comparison of continuous combined transdermal delivery of estradiol-norethindrone acetate and estradiol alone for menopause. CombiPatch Study Group. Obstetrics and Gynecology 94 498-503.

Arlt W, Callies F, van Vlijmen JC, Koehler I, Reincke M, Bidlingmaier M, Huebler D, Oettel M, Ernst M, Schulte HM et al. 1999 Dehydroepiandrosterone replacement in women with adrenal insufficiency. New England Journal of Medicine 341 1013-1020.

Arlt W, Callies F, Koehler I, van Vlijmen JC, Fassnacht M, Strasburger CJ, Seibel MJ, Huebler D, Ernst M, Oettel M et al. 2001 Dehydroepiandrosterone supplementation in healthy men with an age-related decline of dehydroepiandrosterone secretion. Journal of Clinical Endocrinology and Metabolism 86 4686-4692.

Arnst C 2003 Why did prostate cancer death rates fall? Business Week 92

Auclair C, Kelly PA, Labrie F, Coy DH \& Schally AV 1977a Inhibition of testicular luteinizing receptor level by treatment with a potent luteinizing hormone-releasing hormone agonist of human chorionic gonadotropin. Biochemical and Biophysical Research Communications 76 855-862.

Auclair C, Kelly PA, Coy DH, Schally AV \& Labrie F $1977 b$ Potent inhibitory activity of [D-Leu ${ }^{6}$, des-Gly- $\mathrm{NH}_{2}{ }^{10}$ ] ethylamide on LH/hCG and PRL testicular receptor levels in the rat. Endocrinology 101 1890-1893.

Aziz N, Maxwell MM, St Jacques B \& Brenner BM 1993 Downregulation of Ke 6, a novel gene encoded within the major histocompatibility complex, in murine polycystic kidney disease. (Published erratum appears in Molecular and Cellular Biology 199313 6614.) Molecular and Cellular Biology 13 1847-1853.

Bachmann G, Bancroft J, Braunstein G, Burger H, Davis S, Dennerstein L, Goldstein I, Guay A, Leiblum S, Lobo R et al. 2002 Female androgen insufficiency: the Princeton consensus statement on definition, classification, and assessment. Fertility and Sterility 77 660-665.

Baran DT, Bergfeld MA, Teitelbaum SL \& Avioli LV 1978 Effect of testosterone therapy on bone formation in an osteoporotic hypogonadal male. Calcified Tissue Research 26 103-106.

Barbier O, Girard C, Lapointe H, El-Alfy M, Hum DW \& Belanger A 2000 Cellular localization of uridine diphosphoglucuronosyltransferase $2 \mathrm{~B}$ enzymes in the human prostate by in situ hybridization and immunohistochemistry. Journal of Clinical Endocrinology and Metabolism 85 4819-4826.

Basson R 2004 A new model of female sexual desire. Endocrine News 2922.

Baulieu EE 1999 Neuroactive neurosteroids: dehydroepiandrosterone (DHEA) and DHEA sulphate. Acta Paediatrica 88 (Suppl) 78-80.

Baulieu EE, Thomas G, Legrain S, Lahlou N, Roger M, Debuire B, Faucounau V, Girard L, Hervy MP, Latour F et al. 2000 Dehydroepiandrosterone (DHEA), DHEA sulfate, and aging: contribution of the DHEAge Study to a sociobiomedical issue. PNAS 97 4279-4284.

Beaulieu M, Lévesque E, Hum DW \& Bélanger A 1996 Isolation and characterization of novel cDNA encoding a human UDPglucuronosyltransferase active on C19 steroids. Journal of Biological Chemistry $27122855-22862$.

Beaulieu M, Lévesque E, Barbier O, Turgeon D, Bélanger G, Hum DW \& Bélanger A 1997 Isolation and characterization of a simian UDP-glucuronosyltransferase (UGT-2B18) active on 3-hydroxyandrogens. Journal of Molecular Biology 275 785-794. 
Bélanger A, Brochu M \& Cliche J 1986 Levels of plasma steroid glucuronides in intact and castrated men with prostatic cancer. Journal of Clinical Endocrinology and Metabolism 62 812-815.

Bélanger A, Couture J, Caron S \& Roy R 1990 Determination of non-conjugated and conjugated steroid level in plasma and prostate after separation of C-18 columns. In Steroid Formation, Degradation and Action in Peripheral, Normal, and Neoplastic Tissue. Eds H Bradlow, L Castagnetta, S d'Aquino \& F Labrie. Annals of the New York Academy of Sciences 595 251-259.

Bélanger A, Candas B, Dupont A, Cusan L, Diamond P, Gomez JL \& Labrie F 1994 Changes in serum concentrations of conjugated and unconjugated steroids in 40- to 80-year-old men. Journal of Clinical Endocrinology and Metabolism 79 1086-1090.

Bélanger A, Pelletier G, Labrie F, Barbier O \& Chouinard S 2003 Inactivation of androgens by UDP-glucuronosyltransferase enzymes in humans. Trends in Endocrinology and Metabolism 14 473-479.

Bélanger B, Bélanger A, Labrie F, Dupont A, Cusan L \& Monfette G 1989 Comparison of residual C-19 steroids in plasma and prostatic tissue of human, rat and guinea pig after castration: unique importance of extratesticular androgens in men. Journal of Steroid Biochemistry 32 695-698.

Bennett CL, Tosteson TD, Schmitt B, Weinberg PD, Ernstoff MS \& Ross SD 1999 Maximum androgen-blockade with medical or surgical castration in advanced prostate cancer: a meta-analysis of nine published randomized controlled trials and 4128 patients using Flutamide. Prostate Cancer and Prostatic Diseases 2 4-8.

Benz DJ, Haussler MR, Thomas MA, Speelman B \& Komm BS 1991 High-affinity androgen binding and androgenic regulation of $\alpha 1(\mathrm{I})$-procollagen and transforming growth factor- $\beta$ steady state messenger ribonucleic acid levels in human osteoblast-like osteosarcoma cells. Endocrinology 128 2723-2730.

Berger L, El-Alfy M, Martel C \& Labrie F 2005 Effects of dehyroepiandrosterone, Premarin and Acolbifene on histomorphology and sex steroid receptors in the rat vagina. Journal of Steroid Biochemistry and Molecular Biology 96 201-215.

Bergkvist L, Adami HO, Persson I, Hoover R \& Schairer L 1989 The risk of breast cancer after estrogen and estrogen-progestin replacement. New England Journal of Medicine 321 293-297.

Bingham KD \& Shaw DA 1973 The metabolism of testosterone by human male scalp skin. Journal of Endocrinology 57 111-121.

Biswas MG \& Russell DW 1997 Expression cloning and characterization of oxidative $17 \beta$ - and $3 \alpha$-hydroxysteroid dehydrogenase from rat and human prostate. Journal of Biological Chemistry 272 15959-15966.

Bolla M, Gonzalez D, Warde P, Dubois JB, Mirimanoff RO, Storme G, Bernier J, Kuten A, Sternberg C, Gil T et al. 1997 Improved survival in patients with locally advanced prostate cancer treated with radiotherapy and goserelin. New England Journal of Medicine 337 295-300.

Breton R, Yang F, Jin JZ, Li B, Labrie F \& Lin SX 1994 Human $17 \beta$-hydroxysteroid dehydrogenase: overproduction using a baculovirus expression system and characterization. Journal of Steroid Biochemistry and Molecular Biology 50 275-282.

Bulun SE, Zeitoun KM, Takayama K \& Sasano H 2000 Estrogen biosynthesis in endometriosis: molecular basis and clinical relevance. Journal of Molecular Endocrinology 25 35-42.

Burger HG, Hailes J, Menelaus M, Nelson J, Hudson B \& Balazs N 1984 The management of persistent menopausal symptoms with oestradiol-testosterone implants: clinical, lipid and hormonal results. Maturitas 6 351-358.

Cameron DR \& Braunstein GD 2004 Androgen replacement therapy in women. Fertility and Sterility 82 273-289.

Carrier JS, Turgeon D, Journault K, Hum DW \& Belanger A 2000 Isolation and characterization of the human UGT2B7 gene. Biochemical and Biophysical Research Communications 272 616-621.

Cassileth BR, Soloway MS, Vogelzang NJ, Schellhammer PS, Seidmon EJ, Hait HI \& Kennealey GT 1989 Patient's choice of treatment in stage D prostate cancer. Urology 33 57-62.
Casson PR, Andersen RN, Herrod HG, Stentz FB, Straughn AB, Abraham GE \& Buster JE 1993 Oral dehydroepiandrosterone in physiologic doses modulates immune function in postmenopausal women. American Journal of Obstetrics and Gynecology 169 1536-1539.

Caubet JF, Tosteson TD, Dong EW, Naylon EM, Whiting GW, Ernstoff MS \& Ross SD 1997 Maximum androgen blockade in advanced prostate cancer: a meta-analysis of published randomized controlled trials using nonsteroidal antiandrogens. Urology 49 71-78.

Cefalu WT, Wang ZQ, Werbel S, Bell-Farrow A, Crouse JR 3rd, Hinson WH, Terry JG \& Anderson R 1995 Contribution of visceral fat mass to the insulin resistance of aging. Metabolism $\mathbf{4 4}$ 954-959.

Chen C, Poulin R \& Labrie F 1996 Large Shionogi tumors lose their responsiveness to Flutamide treatment. Journal of Steroid Biochemistry and Molecular Biology 48 489-494.

Chesnut CH, Ivey JL, Gruber HE, Matthews M, Nelp WB, Sisom K \& Baylink DJ 1983 Stanozolol in postmenopausal osteoporosis: therapeutic efficacy and possible mechanisms of action. Metabolism 32 571-580.

Christiansen C, Christensen MS, Larsen NE \& Transbol IB 1982 Pathophysiological mechanisms of estrogen effect on bone metabolism. Dose-response relationships in early postmenopausal women. Journal of Clinical Endocrinology and Metabolism $\mathbf{5 5}$ $1124-1130$.

Clarke CL \& Sutherland RL 1990 Progestin regulation of cellular proliferation. Endocrine Reviews 11 266-301.

Cleary MP \& Zisk J 1986 Antiobesity effect of two different levels of dehydroepiandrosterone in lean and obese middle-aged female Zucker rats. International Journal of Obesity 10 193-204.

Coffman BL, Tephly TR, Irshaid YM, Green MD, Smith C, Jackson MR, Wooster R \& Burchell B 1990 Characterization and primary sequence of a human hepatic microsomal estriol UDPglucuronosyltransferase. Archives of Biochemisty and Biophysics 281 170-175.

Colditz GA, Hankinson SE, Hunter DJ, Willett WC, Manson JE, Stampfer MJ, Hennekens C, Rosner B \& Speizer FE 1995 The use of estrogens and progestins and the risk of breast cancer in postmenopausal women. New England Journal of Medicine 332 1589-1593.

Coleman DL, Leiter EH \& Schwizer RW 1982 Therapeutic effects of dehydroepiandrosterone (DHEA) in diabetic mice. Diabetes $\mathbf{3 1}$ 830-833.

Couture P, Thériault C, Simard J \& Labrie F 1993 Androgen receptor-mediated stimulation of $17 \beta$-hydroxysteroid dehydrogenase activity by dihydrotestosterone and medroxyprogesterone acetate in ZR-75-71 human breast cancer cells. Endocrinology 132 179-185.

Couzinet B, Meduri G, Lecce MG, Young J, Brailly S, Loosfelt H, Milgrom E \& Schaison G 2001 The postmenopausal ovary is not a major androgen-producing gland. Journal of Clinical Endocrinology and Metabolism 86 5060-5066.

Crawford ED, Eisenberger MA, McLeod DG, Spaulding JT, Benson R, Dorr FA, Blumenstein BA, Davis MA \& Goodman PJ 1989 A controlled trial of leuprolide with and without flutamide in prostatic carcinoma. New England Journal of Medicine 321 419-424.

Cummings SR, Eckert S, Krueger KA, Grady D, Powles TJ, Cauley JA, Norton L, Nickelsen T, Bjarnason NH, Morrow M et al. 1999 The effect of raloxifene on risk of breast cancer in postmenopausal women: results from the MORE randomized trial. Multiple Outcomes of Raloxifene Evaluation. Journal of the American Medical Association 281 2189-2197.

Cusan L, Dupont A, Gomez JL, Tremblay RR \& Labrie F 1994 Comparison of flutamide and spironolactone in the treatment of hirsutism: a randomized controlled trial. Fertility and Sterility 61 281-287.

D’Amico AV, Manola J, Loffredo M, Renshaw AA, DellaCroce A \& Kantoff PW 2004 6-month androgen suppression plus radiation 
therapy vs radiation therapy alone for patients with clinically localized prostate cancer: a randomized controlled trial. Journal of the American Medical Association 292 821-827.

Dauvois S, Li S, Martel C \& Labrie F 1989 Inhibitory effect of androgens on DMBA-induced mammary carcinoma in the rat. Breast Cancer Research and Treatment 14 299-306.

Dauvois S, Geng CS, Lévesque C, Mérand Y \& Labrie F 1991 Additive inhibitory effects of an androgen and the antiestrogen EM-170 on estradiol-stimulated growth of human ZR-75-71 breast tumors in athymic mice. Cancer Research 51 3131-3135.

Davis SR 2005 Circulating androgen levels do not define female androgen insufficiency. Journal of the American Medical Association. In press.

Davis S \& Tran J 2001 What are 'normal' testosterone levels for women? Journal of Clinical Endocrinology and Metabolism 86 1842-1843.

Davis SR, McCloud P, Strauss BJ \& Burger H 1995 Testosterone enhances estradiol's effects on postmenopausal density and sexuality. Maturitas 21 227-236.

Debruyne F, Delaere P \& Vander Poorten V 2001 Postoperative course of serum parathyroid hormone and calcium after surgery for primary hyperparathyroidism. Acta Oto-rhino-laryngologica Belgica 55 153-157.

De Fazio J, Meldrum DR, Winer JH \& Judd HL 1984 Direct action of androgen on hot flushes in the human male. Maturitas 6 3-8.

Denis L, Carnelro de Moura J, Bono A, Sylvester R, Whelan P, Newling D \& Depauw M 1993 Goserelin acetate and flutamide vs bilateral orchiectomy: a phase III EORTC trial (30853). EORTC GU Group and EORTC Data Center. Urology 42 119-129.

Denis LJ, Keuppens F, Smith PH, Whelan P, de Moura JL, Newling D, Bono A \& Sylvester R 1998 Maximal androgen blockade: final analysis of EORTC Phase III trial 30853. European Urology 33 144-151.

Dennerstein L, Dudley EC, Hopper JL \& Burger H 1997 Sexuality, hormones and the menopausal transition. Maturitas 26 83-93.

Diamond P, Cusan L, Gomez JL, Bélanger A \& Labrie F 1996 Metabolic effects of 12-month percutaneous DHEA replacement therapy in postmenopausal women. Journal of Endocrinology 150 S43-S50.

Dijkman GA, Janknegt RA, Dereijke TM \& Debruyne FMJ 1997 Long-term efficacy and safety of nilutamide plus castration in advanced prostate-cancer, and the significance of early prostate specific antigen normalization. Journal of Urology 158 160-163.

Duan WR, Linzer DIH \& Gibori G 1996 Cloning and characterization of an ovarian-specific protein that associates with the short form of the prolactin receptor. Journal of Biological Chemistry 271 15602-15607.

Dufort I, Rheault P, Huang XF, Soucy P \& Luu-The V 1999 Characteristics of a highly labile human type 517 betahydroxysteroid dehydrogenase. Endocrinology 140 568-574.

Dufort I, Labrie F \& Luu-The V 2001 Human types 1 and 33 alpha-hydroxysteroid dehydrogenases: differential lability and tissue distribution. Journal of Clinical Endocrinology and Metabolism $\mathbf{8 6}$ 841-846.

Dumont M, Luu-The V, de Launoit Y \& Labrie F 1992a Expression of human 17 $\beta$-hydroxysteroid dehydrogenase in mammalian cells. Journal of Steroid Biochemistry and Molecular Biology 41 605-608.

Dumont M, Luu-The V, Dupont E, Pelletier G \& Labrie F $1992 b$ Characterization, expression and immunohistochemical localization of $3 \beta$-hydroxysteroid dehydrogenase $/ \Delta^{5}-\Delta^{4}$ isomerase in human skin. Journal of Investigative Dermatology 99 415-421.

Ebling FJ, Ebling E, McCaffery V \& Skinner J 1971 The response of the sebaceous glands of the hypophysectomized-castrated male rat to 5-dihydrotestosterone, androstenedione, dehydroepiandrosterone and androsterone. Journal of Endocrinology 51 181-190.

Faure N, Labrie F, Lemay A, Bélanger A, Gourdeau Y, Laroche B \& Robert G 1982 Inhibition of serum androgen levels by chronic intranasal and subcutaneous administration of a potent luteinizing hormone-releasing hormone (GNRH) agonist in adult men. Fertility and Sterility 37 416-424.

Ferrannini E, Natali A, Capaldo B, Lehtovirta M, Jacob S \& Yki-Jarvinen H 1997 Insulin resistance, hyperinsulinemia, and blood pressure: role of age and obesity. European Group for the Study of Insulin Resistance (EGIR). Hypertension 30 1144-1149.

Field CS, Ory SJ, Wahner HW, Herrmann RR, Judd HL \& Riggs BL 1993 Preventive effects of transdermal 17-beta estradiol on osteoporotic changes after surgical menopause: a two year placebo controlled trial. American Journal of Obstetrics and Gynecology 168 114-121.

Flamigni CA, Collins WP, Koullapis EN \& Sommerville IF 1970 Formation and metabolism of testosterone in rat skin. Endocrinology 87 764-770.

Flynn MA, Weaver-Osterholtz D, Sharpe-Timms KL, Allen S \& Krause G 1999 Dehydroepiandrosterone replacement in aging humans. Journal of Clinical Endocrinology and Metabolism $\mathbf{8 4}$ $1527-1533$

Garland CF, Friedlander NJ, Barrett-Connor E \& Khaw KT 1992 Sex hormones and postmenopausal breast cancer: a prospective study in an adult community. American Journal of Epidemiology 135 1220-1230.

Geissler WM, Davis DL, Wu L, Bradshaw KD, Patel S, Mendoça BB, Elliston KO, Wilson JD, Russel DW \& Andersson S 1994 Male pseudohermaphroditism caused by mutations of testicular 17ß-hydroxysteroid dehydrogenase 3. Nature Genetics 7 34-39.

Genant HK, Baylink DJ, Gallagher JC, Harris ST, Steiger P \& Herber M 1990 Effect of estrone sulfate on postmenopausal bone loss. Obstetrics and Gynecology 76 579-584.

Ghosh D, Pletnev VZ, Zhu DW, Wawrzak Z, Duax WL, Pangborn W, Labrie F \& Lin SX 1995 Structure of human estrogenic $17 \beta$-hydroxysteroid dehydrogenase at $2 \cdot 20 \mathrm{~A}$ resolution. Structure 3 503-513.

Goldstat R, Briganti E, Tran J, Wolfe R \& Davis SR 2003 Transdermal testosterone therapy improves well-being, mood, and sexual function in premenopausal women. Menopause 10 390-398.

Gordon GB, Shantz LM \& Talalay P 1987 Modulation of growth, differentiation and carcinogenesis by dehydroepiandrosterone. Advances in Enzyme Regulation 26 355-382.

Goss PE, Ingle JN, Martino S, Robert NJ, Muss HB, Piccart MJ, Castiglione M, Tu D, Shepherd LE, Pritchard KI et al. 2003 A randomized trial of letrozole in postmenopausal women after five years of tamoxifen therapy for early-stage breast cancer. New England Journal of Medicine 349 1793-1802.

Grady D, Rubin SM, Petitti DB, Fox CS, Black D, Ettinger B, Ernster VL \& Cummings SR 1992 Hormone therapy to prevent disease and prolong life in postmenopausal women. Annals of Internal Medicine 117 1016-1037.

Granfors T, Modig H, Damber JE \& Tomic R 1998 Combined orchiectomy and external radiotherapy versus radiotherapy alone for nonmetastatic prostate cancer with or without pelvic lymph node involvement: a prospective randomized study. Journal of Urology 159 2030-2034.

Greenblatt RB, Barfield WE, Garner JF, Calk GL \& Harrod JP Jr 1950 Evaluation of an estrogen, androgen, estrogen-androgen combination, and a placebo in the treatment of the menopause. Journal of Clinical Endocrinology and Metabolism 10 1547-1558.

Greendale GA \& Judd HL 1993 The menopause: health implications and clinical management. Journal of the American Geriatrics Society $\mathbf{4 1}$ 426-436.

Grody MH, Lampe EH \& Masters WH 1953 Estrogen-androgen substitution therapy in the aged female. I. Uterine bioassay report. Obstetrics and Gynecology 2 36-45.

Hackbert L \& Heiman JR 2002 Acute dehydroepiandrosterone (DHEA) effects on sexual arousal in postmenopausal women. Journal of Women's Health and Gender-Based Medicine 11 155-162. 
Han DH, Hansen PA, Chen MM \& Holloszy JO 1998 DHEA treatment reduces fat accumulation and protects against insulin resistance in male rats. Journal of Gerontology. Series A, Biological Sciences and Medical Sciences 53 B19-B24.

Hanks GE, Lu J, Machtay M, Venkatesan V, Pinover W, Byhardt R \& Rosenthal SA 2000 RTOG Protocol 92-02: a phase III trial of the use of long term androgen suppression following neoadjuvant hormonal cytoreduction and radiotherapy in locally advanced carcinoma of the prostate. 36th Annual Meeting of the American Society of Clinical Oncology, New Orleans, LA, USA, 1284.

Hansen PA, Han DH, Nolte LA, Chen M \& Holloszy JO 1997 DHEA protects against visceral obesity and muscle insulin resistance in rats fed a high-fat diet. American Journal of Physiology - Regulatory, Integrative and Comparative Physiology 273 R1704-R1708.

Harris ST, Genant HK, Baylink DJ, Gallagher JC, Karp SK, McConnell MA, Green EM \& Stoll RW 1991 The effects of estrone (Ogen) on spinal bone density of postmenopausal women. Archives of Internal Medicine 151 1980-1984.

Henderson E, Yang JY \& Schwartz A 1992 Dehydroepiandrosterone (DHEA) and sysnthetic DHEA analogs are modest inhibitors of HIV-1 IIIB replication. Aids Research and Human Retroviruses 8 625-631.

Hennernan PM \& Wallach S 1957 The role of androgens and estrogens and their metabolic effects. A review of the prolonged use of estrogens and androgens in postmenopausal and senile osteoporosis. Archives of Internal Medicine 100 715-723.

Horton R 1992 Dihydrotestosterone is a peripheral paracrine hormone. Journal of Andrology 13 23-27.

Horton R \& Lobo R 1986 Peripheral androgens and the role of androstanediol glucuronide. Clinical Endocrinology and Metabolism $\mathbf{1 5}$ 293-306.

Horwitz KB 1992 The molecular biology of RU486. Is there a role for antiprogestins in the treatment of breast cancer? Endocrine Reviews 13 146-163.

Huang X-F \& Luu-The V 2000 Molecular characterization of a first human 3 (alpha-beta)-hydroxysteroid epimerase. Journal of Biological Chemistry 275 29452-29457.

Huang XF \& Luu-The V 2001a Characterization of the oxidative 3 alpha-hydroxysteroid dehydrogenase activity of human recombinant 11-cis-retinol dehydrogenase. Biochimica et Biophysica Acta 1547 351-358.

Huang XF \& Luu-The V $2001 b$ Gene structure, chromosomal localization and analysis of 3-ketosteroid reductase activity of the human 3(alpha $\rightarrow$ beta)-hydroxysteroid epimerase. Biochimica et Biophysica Acta 1520 124-130.

Janknegt RA, Abbou CC, Bartoletti R, Bernstein-Hahn L, Bracken B, Brisset JM, Da Silva FC, Chisholm G, Crawford ED, Debruyne FMJ et al. 1993 Orchiectomy and nilutamide or placebo as treatment of metastatic prostatic cancer in a multinational doubleblind randomized trial. Journal of Urology 149 77-83.

Jedrzejuk D, Medras M, Milewicz A \& Demissie M 2003 Dehydroepiandrosterone replacement in healthy men with age-related decline of DHEA-S: effects on fat distribution, insulin sensitivity and lipid metabolism. Aging Male 6 151-156.

Jemal A, Murray T, Ward E, Samuels A, Tiwari RC, Ghafoor A, Feuer EJ \& Thun MJ 2005 Cancer statistics, 2005. CA: A Cancer Journal for Clinicians $\mathbf{5 5}$ 10-30.

Jenkins EP, Hsieh CL, Milatovich A, Normington K, Berman DM, Francke U \& Russel DW 1991 Characterization and chromosomal mapping of human steroid $5 \alpha$-reductase gene and pseudogene and mapping of the mouse homologue. Genomics 11 1102-1112.

Kapur SP \& Reddi AH 1989 Influence of testosterone and dihydrotestosterone on bone-matrix induced endochondral bone formation. Calcified Tissue International 44 108-113.

Kawano H, Yasue H, Kitagawa A, Hirai N, Yoshida T, Soejima H, Miyamoto S, Nakano M \& Ogawa H 2003
Dehydroepiandrosterone supplementation improves endothelial function and insulin sensitivity in men. Journal of Clinical Endocrinology and Metabolism 88 3190-3195.

Kikuti YY, Tamiya G, Ando A, Chen L, Kimura M, Ferreira E, Tsuji K, Trowsdale J \& Inoko H 1997 Physical mapping $220 \mathrm{~kb}$ centromeric of the human MHC and DNA sequence analysis of the 43-kb segment including the RING1, HKE6, and HKE4 genes. Genomics 42 422-435.

Klotz L 2001 Combined androgen blockade in prostate cancer: meta-analyses and associated issues. British Journal of Urology 87 806-813.

Klotz LH 2003 Selling ourselves short. Canadian Journal of Urology 10 1969.

Kopelman PG 2000 Obesity as a medical problem. Nature 404 635-643.

Krazeisen A, Breitling R, Imai K, Fritz S, Moller G \& Adamski J 1999 Determination of cDNA, gene structure and chromosomal localization of the novel human 17 beta-hydroxysteroid dehydrogenase type 7(1). FEBS Letters 460 373-379.

Kuttenn F, Mowszowicz I, Wright F, Baudot N, Jaffiol C, Robin M \& Mauvais-Jarvis P 1979 Male pseudohermaphroditism: a comparative study of one patient with $5 \alpha$-reductase deficiency and three patients with the complete form of testicular feminization. Journal of Clinical Endocrinology and Metabolism 49 861-865.

Labrie F 1991 Intracrinology. Molecular and Cellular Endocrinology 78 C113-C118.

Labrie F 2000a Screening and early hormonal treatment of prostate cancer are accumulating strong evidence and support. Prostate 43 215-222.

Labrie F $2000 b$ Prostate cancer and combined androgen blockade at all stages of disease. In Progress in Anti-Cancer Chemotherapy, pp 171-187. Eds D Khayat \& GN Hortobagyi. France, Berlin, Heidelberg: Springer.

Labrie F 2002 Endocrine-sensitive cancers of the prostate and breast. In Genetics in Endocrinology, pp 607-661. Eds J Baxter, S Melmed \& MI New. Philadelphia: Lippincott-William and Wilkins.

Labrie C, Bélanger A \& Labrie F 1988 Androgenic activity of dehydroepiandrosterone and androstenedione in the rat ventral prostate. Endocrinology 123 1412-1417.

Labrie C, Simard J, Zhao HF, Bélanger A, Pelletier G \& Labrie F 1989 Stimulation of androgen-dependent gene expression by the adrenal precursors dehydroepiandrosterone and androstenedione in the rat ventral prostate. Endocrinology 124 2745-2754.

Labrie F, Bélanger A, Cusan L, Séguin C, Pelletier G, Kelly PA, Reeves JJ, Lefebvre FA, Lemay A \& Raynaud JP 1980 Antifertility effects of LHRH agonists in the male. Journal of Andrology $\mathbf{1}$ 209-228.

Labrie F, Dupont A, Bélanger A, Cusan L, Lacourcière Y, Monfette G, Laberge JG, Emond J, Fazekas AT, Raynaud JP et al. 1982 New hormonal therapy in prostatic carcinoma: combined treatment with an LHRH agonist and an antiandrogen. Clinical Investigation and Medicine 5 267-275.

Labrie F, Dupont A \& Bélanger A 1985 Complete androgen blockade for the treatment of prostate cancer. In Important Advances in Oncology, pp 193-217. Eds VT de Vita, S Hellman \& SA Rosenberg. Philadelphia: J.B. Lippincott.

Labrie F, Simard J, Luu-The V, Bélanger A \& Pelletier G 1992a Structure, function and tissue-specific gene expression of $3 \beta$-hydroxysteroid dehydrogenase/5-ene-4-ene isomerase enzymes in classical and peripheral intracrine steroidogenic tissues. Journal of Steroid Biochemistry and Molecular Biology 43 805-826.

Labrie F, Sugimoto Y, Luu-The V, Simard J, Lachance Y, Bachvarov D, Leblanc G, Durocher F \& Paquet N $1992 b$ Structure of human type II 5a-reductase. Endocrinology 131 1571-1573.

Labrie F, Bélanger A, Simard J, Luu-The V \& Labrie C 1995a DHEA and peripheral androgen and estrogen formation: intracrinology. Annals of the New York Academy of Sciences 774 16-28. 
Labrie F, Bélanger A, Cusan L, Simard J, Luu-The V, Labrie C, Gomez JL, Diamond P \& Candas B 1996a History of LHRH agonists and combination therapy in prostate cancer. Endocrine-Related Cancer 3 243-278.

Labrie F, Simard J, Luu-The V, Bélanger A, Pelletier G, Morel Y, Mebarki F, Sanchez R, Durocher F, Turgeon C et al. $1996 b$ The $3 \beta$-hydroxysteroid dehydrogenase/isomerase gene family: lessons from type II $3 \beta-H S D$ congenital deficiency. In Signal Transduction in Testicular Cells. Ernst Schering Research Foundation Workshop, pp 185-218. Eds V Hansson, FO Levy \& K Taskén. Berlin, Heidelberg, New York: Springer-Verlag.

Labrie F, Belanger A, Cusan L \& Candas B 1997a Physiological changes in dehydroepiandrosterone are not reflected by serum levels of active androgens and estrogens but of their metabolites: intracrinology. Journal of Clinical Endocrinology and Metabolism 82 2403-2409.

Labrie F, Diamond P, Cusan L, Gomez JL \& Bélanger A 1997b Effect of 12-month DHEA replacement therapy on bone, vagina, and endometrium in postmenopausal women. Journal of Clinical Endocrinology and Metabolism 82 3498-3505.

Labrie F, Bélanger A, Cusan L, Gomez JL \& Candas B 1997c Marked decline in serum concentrations of adrenal C19 sex steroid precursors and conjugated androgen metabolites during aging. Journal of Clinical Endocrinology and Metabolism 82 2396-2402.

Labrie F, Luu-The V, Lin SX, Labrie C, Simard J, Breton R \& Bélanger A 1997d The key role of $17 \beta$-HSDs in sex steroid biology. Steroids 62 148-158.

Labrie F, Cusan L, Gomez JL, Belanger A \& Candas B 1999a Long-term combined androgen blockade alone for localized prostate cancer. Molecular Urology 3 217-225.

Labrie F, Candas B, Dupont A, Cusan L, Gomez JL, Suburu RE, Diamond P, Lévesque J \& Bélanger A 1999b Screening decreases prostate cancer death: first analysis of the 1988 Quebec prospective randomized controlled trial. Prostate 38 83-91.

Labrie F, Luu-The V, Lin S-X, Simard J \& Labrie C 2000a Role of $17 \beta$-hydroxysteroid dehydrogenases in sex steroid formation in peripheral intracrine tissues. Trends in Endocrinolgy and Metabolism 11 421-427.

Labrie F, Luu-The V, Lin S-X, Simard J, Labrie C, El-Alfy M, Pelletier G \& Bélanger A $2000 b$ Intracrinology: role of the family of $17 \beta$-hydroxysteroid dehydrogenases in human physiology and disease. Journal of Molecular Endocrinology 25 1-16.

Labrie F, Luu-The V, Labrie C \& Simard J 2001 DHEA and its transformation into androgens and estrogens in peripheral target tissues: intracrinology. Frontiers in Neuroendocrinology 22 185-212.

Labrie F, Candas B, Gomez JL \& Cusan L 2002 Can combined androgen blockade provide long-term control or possible cure of localized prostate cancer? Urology 60 115-119.

Labrie F, Luu-the V, Labrie C, Bélanger A, Simard J, Lin S-X \& Pelletier G 2003a Endocrine and intracrine sources of androgens in women: inhibition of breast cancer and other roles of androgens and their precursor dehydroepiandrosterone. Endocrine Reviews $\mathbf{2 4}$ 152-182.

Labrie F, El-Alfy M, Berger L, Labrie C, Martel C, Bélanger A, Candas B \& Pelletier G $2003 b$ The combination of a novel SERM with an estrogen protects the mammary gland and uterus in a rodent model: the future of postmenopausal women's health? Endocrinology 144 4700-4706.

Labrie Y, Durocher F, Lachance Y, Turgeon C, Simard J, Labrie C \& Labrie F 1995 b The human type II $17 \beta$-hydroxysteroid dehydrogenase gene encodes two alternatively-spliced messenger RNA species. DNA Cell Biology 14 849-861.

Lachance Y, Luu-The V, Labrie C, Simard J, Dumont M, de Launoit Y, Guérin S, Leblanc G \& Labrie F 1990 Characterization of human $3 \beta$-hydroxysteroid dehydrogenase $/ \Delta^{5}-\Delta^{4}$ isomerase gene and its expression in mammalian cells. Journal of Biological Chemistry 265 20469-20475.
Lachance Y, Luu-The V, Verreault H, Dumont M, Rhéaume E, Leblanc G \& Labrie F 1991 Structure of the human type II

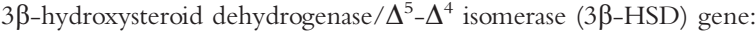
adrenal and gonadal specificity. DNA Cell Biology 10 701-711.

Laughlin GA \& Barrett-Connor E 2000 Sexual dimorphism in the influence of advanced aging on adrenal hormone levels: the Rancho Bernardo Study. Journal of Clinical Endocrinology and Metabolism 85 3561-3568.

Laumann EO, Paik A \& Rosen RC 1999 Sexual dysfunction in the United States: prevalence and predictors. Journal of the American Medical Association 281 537-544.

de Launoit Y \& Adamski J 1999 Unique multifunctional HSD17B4 gene product: 17 beta-hydroxysteroid dehydrogenase 4 and D-3-hydroxyacyl-coenzyme A dehydrogenase/hydratase involved in Zellweger syndrome. Journal of Molecular Endocrinology 22 227-240.

Leenders F, Adamski J, Husen B, Thole HH \& Jungblut PW 1994 Molecular cloning and amino acid sequence of the porcine 17 beta-estradiol dehydrogenase. European Journal of Biochemistry 222 221-227.

Leiblum S, Bachmann G, Kemmann E, Colburn D \& Swartzman L 1983 Vaginal atrophy in the postmenopausal women. The importance of sexual activity and hormones. Journal of the American Medical Association 249 2195-2198.

Levesque E, Turgeon D, Carrier JS, Montminy V, Beaulieu M \& Belanger A 2001 Isolation and characterization of the UGT2B28 cDNA encoding a novel human steroid conjugating UDPglucuronosyltransferase. Biochemistry 40 3869-3881.

Li S, Yan X, Bélanger A \& Labrie F 1993 Prevention by dehydroepiandrosterone of the development of mammary carcinoma induced by 7,12-dimethylbenz(a)anthracene (DMBA) in the rat. Breast Cancer Research and Treatment 29 203-217.

Liang T, Rasmusson GH \& Brooks JR 1983 12. Androgens: pharmacodynamics and antagonists. Biochemical and biological studies with 4 -aza-steroidal $5 \alpha$-reductase inhibitors. Journal of Steroid Biochemistry 19 385-390.

Lin SX, Yang F, Jin JZ, Breton R, Zhu DW, Luu-The V \& Labrie F 1992 Subunit identity of the dimeric $17 \beta$-hydroxysteroid dehydrogenase from human placenta. Journal of Biological Chemistry 267 16182-16187.

Lindsay R 1993 Hormone replacement therapy for prevention and treatment of osteoporosis. American Journal of Medicine 95 37S-39S.

Lipworth L, Adami HO, Trichopoulos D, Carlstrom K \& Matzoros C 1996 Serum steroid hormone levels, sex hormone-binding globulin, and body mass index in the etiology of postmenopausal breast cancer. Epidemiology 7 96-100.

Liu H, Robert A \& Luu-The V 2005 Cloning and characterization of human form 2 type 17 beta-hydroxysteroid dehydrogenase. A primarily 3 beta-keto reductase and estrogen activating enzyme. Journal of Steroid Biochemistry and Molecular Biology 94 173-179.

Lobo RA, Rosen RC, Yang HM, Block B \& Van Der Hoop RG 2003 Comparative effects of oral esterified estrogens with and without methyltestosterone on endocrine profiles and dimensions of sexual function in postmenopausal women with hypoactive sexual desire. Fertility and Sterility 79 1341-1352.

Lomax P \& Schonbaum E 1993 Postmenopausal hot flushes and their management. Pharmacology and Therapeutics 57 347-358.

Lunglmayr G, Girsch E, Meixner EM, Viehberger G \& Bieglmayer C 1988 Effects of long term GnRH analogue treatment on hormone levels and spermatogenesis in patients with carcinoma of the prostate. Urology Research 16 315-319.

Luu-The V 2001 Analysis and characteristics of multiple types of human 17 beta-hydroxysteroid dehydrogenase. Journal of Steroid Biochemistry and Molecular Biology 76 143-151.

Luu-The V, Lachance Y, Labrie C, Leblanc G, Thomas JL, Strickler RC \& Labrie F 1989a Full length cDNA structure and deduced amino acid sequence of human $3 \beta$-hydroxy-5-ene steroid dehydrogenase. Molecular Endocrinology 3 1310-1312. 
Luu-The V, Labrie C, Zhao HF, Couët J, Lachance Y, Simard J, Leblanc G, Côté J, Bérubé D, Gagné R et al. 1989b Characterization of cDNAs for human estradiol 17 $\beta$-dehydrogenase and assignment of the gene to chromosome 17: evidence of two mRNA species with distinct $5^{\prime}$ termini in human placenta. Molecular Endocrinology 3 1301-1309.

Luu-The V, Labrie C, Simard J, Lachance Y, Zhao HF, Couët J, Leblanc G \& Labrie F 1990a Structure of two in tandem human $17 \beta$-hydroxysteroid dehydrogenase genes. Molecular Endocrinology 4 268-275.

Luu-The V, Labrie C, Zhao HF, Couet J, Lachance Y, Simard J, Côté J, Leblanc J, Lagacé L, Bérubé D et al. 1990 b Purification, cloning complementary DNA structure and predicted amino acid sequence of human estradiol $17 \beta$-dehydrogenase. Annals of the New York Academy of Sciences 595 40-52.

Luu-The V, Takahashi M, de Launoit Y, Dumont M, Lachance Y \& Labrie F 1991 Evidence for distinct dehydrogenase and isomerase sites within a single $3 \beta$-hydroxysteroid dehydrogenase 5 -ene-4-eneisomerase protein. Biochemistry 30 8861-8865.

Luu-The V, Sugimoto Y, Puy L, Labrie Y, Lopez Solache I, Singh M \& Labrie F 1994 Characterization, expression and immunohistochemical localization of $5 \alpha$-reductase in human skin. Journal of Investigative Dermatology 102 221-226.

Luu-The V, Zhang Y, Poirier D \& Labrie F 1995a Characteristics of human types 1, 2 and $317 \beta$-hydroxysteroid dehydrogenase activities: oxidation-reduction and inhibition. Journal of Steroid Biochemistry and Molecular Biology 55 581-587.

Luu-The V, Dufort I, Paquet N, Reimnitz G \& Labrie F 1995 b Structural characterization and expression of the human dehydroepiandrosterone sulfotransferase gene. DNA Cell Biology 14 511-518.

Luu-The V, Dufort I, Pelletier G \& Labrie F 2001 Type 5 $17 \beta$-hydroxysteroid dehydrogenase: its role in the formation of androgens in women. Molecular and Cellular Endocrinology 171 $77-82$.

MacEwen EG \& Kurzman ID 1991 Obesity in the dog: role of the adrenal steroid dehydroepiandrosterone (DHEA). Journal of Nutrition 121 S51-S55.

Mackenzie PI, Owens IS, Burchell B, Bock KW, Bairoch A, Belanger A, Fournel-Gigleux S, Green M, Hum DW, Iyanagi T et al. 1997 The UDP glycosyltransferase gene superfamily: recommended nomenclature update based on evolutionary divergence. Pharmacogenetics 7 255-269.

Magnusson C, Baron JA, Correia N, Bergstrom R, Adami HO \& Persson I 1999 Breast-cancer risk following long-term oestrogenand oestrogen-progestin-replacement therapy. International Journal of Cancer 81 339-344.

Martel C, Melner MH, Gagné D, Simard J \& Labrie F 1994 Widespread tissue distribution of steroid sulfatase, $3 \beta$-hydroxysteroid dehydrogenase $/ \Delta^{5}-\Delta^{4}$ isomerase ( $3 \beta$-HSD), $17 \beta$-HSD $5 \alpha$-reductase and aromatase activities in the rhesus monkey. Molecular and Cellular Endocrinology 104 103-111.

Martel C, Sourla A, Pelletier G, Labrie C, Fournier M, Picard S, Li S, Stojanovic M \& Labrie F 1998 Predominant androgenic component in the stimulatory effect of dehydroepiandrosterone on bone mineral density in the rat. Journal of Endocrinology 157 433-442.

Mauvais-Jarvis P, Bercovici JP \& Gauthier F 1969 In vivo studies on testosterone metabolism by skin of normal males and patients with the syndrome of testicular feminization. Journal of Clinical Endocrinology and Metabolism 29 417-421.

Mehring J 2004 Do drugs make a dent? Business Week 5 April, p 32.

Messing EM, Manola J, Sarosdy M, Wilding G, Crawford ED \& Trump D 1999 Immediate hormonal therapy compared with observation after radical prostatectomy and pelvic lymphadenectomy in men with node-positive prostate cancer. New England Journal of Medicine 341 1781-1788.

Mettlin C, Natarajan N \& Murphy GP 1982 Recent patterns of care of prostatic cancer patients in the United States: results from the surveys of the American College of Surgeons Commission on Cancer. International Advances in Surgical Oncology 5 277-321.

Migeon CJ, Keller AR, Lawrence B \& Shepart TH II 1957 Dehydroepiandrosterone and androsterone levels in human plasma. Effect of age and sex: day-to-day and diurnal variations. Journal of Clinical Endocrinology and Metabolism 17 1051-1062.

Milewich L, Shaw CE, Mason JI, Carr BR, Blomquist CH \& Thomas JL 1993 3ß-hydroxysteroid dehydrogenase activity in tissues of human fetus determined with $5 \alpha$-androstane- $3 \beta, 17 \beta$-diol and dehydroepiandrosterone as substrates. Journal of Steroid Biochemistry and Molecular Biology 45 525-537.

Miller KK, Biller BM, Hier J, Arena E \& Klibanski A 2002 Androgens and bone density in women with hypopituitarism. Journal of Clinical Endocrinology and Metabolism 87 2770-2776.

Miller KK, Rosner W, Lee H, Hier J, Sesmilo G, Schoenfeld D, Neubauer G \& Klibanski A 2004 Measurement of free testosterone in normal women and women with androgen deficiency: comparison of methods. Journal of Clinical Endocrinology and Metabolism 89 525-533.

Milne JA 1969 The metabolism of androgens by sebaceous glands. British Journal of Dermatology 81 22-28.

Moghissi E, Ablan F \& Horton R 1984 Origin of plasma androstanediol glucuronide in men. Journal of Clinical Endocrinology and Metabolism 59 417-421.

Mohan PF, Ihnen JS, Levin BE \& Cleary MP 1990 Effects of dehydroepiandrosterone treatment in rats with diet-induced obesity. Journal of Nutrition 120 1103-1114.

Morales AJ, Nolan JJ, Nelson JC \& Yen SS 1994 Effects of replacement dose of dehydroepiandrosterone in men and women of advancing age. Journal of Clinical Endocrinology and Metabolism 78 $1360-1367$.

Morissette J, Rhéaume E, Leblanc JF, Luu-The V, Labrie F \& Simard J 1995 Genetic linkage mapping of the HSD3B1 and HSD3B2 genes encoding human types I and II $3 \beta$-hydroxysteroid dehydrogenase $/ \Delta^{5}-\Delta^{4}$ isomerase close to D1S514 and the centromeric D1Z5 locus. Cytogenetics and Cell Genetics 69 59-62.

Mouridsen H, Gershanovich M, Sun Y, Perez-Carrion R, Boni C, Monnier A, Apffelstaed J, Smith R, Sleeboom HP, Jaenicke F et al. 2003 Phase III study of letrozole versus tamoxifen as first-line therapy of advanced breast cancer in postmenopausal women: analysis of survival and update of efficacy from the International Letrozole Breast Cancer Group. Journal of Clinical Oncology 21 2101-2109.

Muir AV, Hodgins MB, Milne JA \& Young H 1970 The presence of hydroxysteroid dehydrogenase in mammalian sebaceous structures. British Journal of Dermatology 83 291-295.

Murphy GP, Beckley S, Brady MF, Chut M, deKernion JB, Dhabuwala C, Gaeta JF, Gibbons RP, Loening SA, McKiel CF et al. 1983 Treatment of newly diagnosed metastatic prostate cancer patients with chemotherapy agents in combination with hormones versus hormones alone. Cancer 51 1264-1272.

Musgrove EA, Lee CS \& Sutherland RL 1991 Progestins both stimulate and inhibit breast cancer cell cycle progression while increasing expression of transforming growth factor alpha, epidermal growth factor receptor, $\mathrm{c}-\mathrm{fos}$, and $\mathrm{c}-\mathrm{myc}$ genes. Molecular and Cellular Biology 11 5032-5043.

Nabholtz JM, Buzdar A, Pollak M, Harwin W, Burton G, Mangalik A, Steinberg M, Webster A \& von Euler M 2000 Anastrozole is superior to tamoxifen as first-line therapy for advanced breast cancer in postmenopausal women: results of a North American multicenter randomized trial. Arimidez Study Group. Journal of Clinical Oncology 18 3758-3767.

Nathorst-Boos J \& von Schoultz B 1992 Psychological reactions and sexual life after hysterectomy with and without oophorectomy. Gynecologic and Obstetric Investigation 34 97-101.

Need AG, Horowitz M, Morris HA, Walker CJ \& Nordin BE 1987 Effects of nandrolone therapy on forearm bone mineral content in osteoporosis. Clinical Orthopaedics and Related Research 225 273-278. 
Need AG, Horowitz M, Bridges A, Morris HA \& Nordin BE 1989 Effects of nandrolone decanoate and antiresorptive therapy on vertebral density in osteoporotic postmenopausal women. Archives of Internal Medicine 149 57-60.

Nesbit RM \& Baum WC 1950 Endocrine control of prostatic carcinoma: clinical and statistical survey of 1818 cases. Journal of the American Medical Association 143 1317-1320.

Nestler JE, Barlascini CO, Clore JN \& Blackard WG 1988 Dehydroepiandrosterone reduces serum low density lipoprotein levels and body fat but does not alter insulin sensitivity in normal men. Journal of Clinical Endocrinology and Metabolism 66 57-61.

Nokelainen P, Peltoketo H, Vihko R \& Vihko P 1998 Expression cloning of a novel estrogenic mouse 17 beta-hydroxysteroid dehydrogenase/17-ketosteroid reductase (m17 HSD7), previously described as a prolactin receptor-associated protein (PRAP) in rat. Molecular Endocrinology 12 1048-1059.

Notelovitz M, Watts N, Timmons C, Addison A, Wiita B \& Downey L 1991 Effects of estrogen plus low dose androgen vs estrogen alone on menopausal symptoms in oophorectomized/hysterectomized women. Proceedings of the North American Menopause Society, Montreal, Canada, p 101.

Orentreich N, Brind JL, Rizer RL \& Vogelman JH 1984 Age changes and sex differences in serum dehydroepiandrosterone sulfate concentrations throughout adulthood. Journal of Clinical Endocrinology and Metabolism 59 551-555.

Peeling WB 1989 Phase III studies to compare goserelin (Zoladex) with orchiectomy and with diethylstilbestrol in treatment of prostatic carcinoma. Urology 33 45-52.

Pelletier G, Dupont E, Simard J, Luu-The V, Bélanger A \& Labrie F 1992 Ontogeny and subcellular localization of $3 \beta$-hydroxysteroid dehydrogenase $(3 \beta-\mathrm{HSD})$ in the human and rat adrenal, ovary and testis. Journal of Steroid Biochemistry and Molecular Biology 43 451-467.

Pelletier G, Luu-The V, Huang XF, Lapointe H \& Labrie F 1998 Localization by in situ hybridization of steroid $5 \alpha$-reductase isozyme gene expression in the human prostate and preputial skin. Journal of Urology $160577-582$.

Pelletier G, Luu-The V, Tetu B \& Labrie F 1999 Immunocytochemical localization of type $517 \beta$-hydroxysteroid dehydrogenase in human reproductive tissues. Journal of Histochemistry and Cytochemistry 47 731-737.

Pelletier G, Luu-The V, El-Alfy M, Li S \& Labrie F 2001 Immunoelectron microscopic localization of $3 \beta$-hydroxysteroid dehydrogenase and type $517 \beta$-hydroxysteroid dehydrogenase in the human prostate and mammary gland. Journal of Molecular Endocrinology 26 11-19.

Peltoketo H, Isomaa V, Mä entausta O \& Vihko R 1988 Complete amino acid sequence of human placental $17 \beta$-hydroxysteroid dehydrognease deduced from cDNA. FEBS Letters 239 73-77.

Peltoketo H, Isomaa V \& Vihko R 1992 Genomic organization and DNA sequences of human $17 \beta$-hydroxysteroid dehydrogenase genes and flanking regions: localization of multiple Alu sequences and putative cis-acting elements. European Journal of Biochemistry 209 459-466.

Persson 1999 Risks of breast and endometrial cancer after estrogen and estrogen-progestin replacement. Cancer Causes Control 10 253-260.

Peto R \& Dalesio O 2003 Breast and prostate cancer: 10-year survival gains in the hormonal adjuvant treatment trials. European Congress of Clinical Oncology 12, Copenhagen. S101.

Pilepich MV, Caplan R, Byhardt RW, Lawton CA, Gallagher MJ, Mesic JB, Hanks GE, Coughlin CT, Porter A, Shipley WU et al. 1997 Phase III trial of androgen suppression using Goserelin in unfavorable prognosis carcinoma of the prostate treated with definitive radiotherapy: report of Radiation Therapy Oncology Group protocol 85-31. Journal of Clinical Oncology 15 1013-1021.

Poortman J, Thijssen JH, von Landeghem AA, Wiegerinck MA \& Alsbach GP 1983 Subcellular distribution of androgens and oestrogens in target tissue. Journal of Steroid Biochemistry 19 939-945.
Poulin R \& Labrie F 1986 Stimulation of cell proliferation and estrogenic response by adrenal C19- $\Delta^{5}$-steroids in the ZR-75-71 human breast cancer cell line. Cancer Research 46 4933-4937.

Poulin R, Baker D \& Labrie F 1988 Androgens inhibit basal and estrogen-induced cell proliferation in the ZR-75-71 human breast cancer cell line. Breast Cancer Research and Treatment 12 213-225.

Poulin R, Simard J, Labrie C, Petitclerc L, Dumont M, Lagacé L \& Labrie F 1989 Down-regulation of estrogen receptors by androgens in the ZR-75-71 human breast cancer cell line. Endocrinology 125 392-399.

Prostate Cancer Triallists' Collaborative Group 2000 Maximum androgen blockade in advanced prostate cancer: an overview of the randomised trials. Lancet 355 1491-1498.

Pye JK, Mansel RE \& Hughes LE 1985 Clinical experience of drug treatments for mastalgia. Lancet ii 373-377.

Qiu W, Zhou M, Labrie F \& Lin SX 2004 Crystal structures of the multispecific 17 beta-hydroxysteroid dehydrogenase type 5: critical androgen regulation in human peripheral tissues. Molecular Endocrinology 18 1798-1807.

Raisz LG, Wiita B, Artis A, Bowen A, Schwartz S, Trahiotis M, Shoukri K \& Smith J 1996 Comparison of the effects of estrogen alone and estrogen plus androgen on biochemical markers of bone formation and resorption in postmenopausal women. Journal of Clinical Endocrinology and Metabolism 81 37-43.

Rasmussen KR, Arrowood MJ \& Healey MC 1992 Effectiveness of dehydroepiandrosterone in reduction of cryptosporidial activity in immunosuppressed rats. Antimicrobial Agents and Chemotherapy 36 220-222.

Rhéaume E, Lachance Y, Zhao HF, Breton N, Dumont M, de Launoit Y, Trudel C, Luu-The V, Simard J \& Labrie F 1991 Structure and expression of a new cDNA encoding the almost exclusive $3 \beta$-hydroxysteroid dehydrogenase $/ \Delta^{5}-\Delta^{4}$ isomerase in human adrenals and gonads. Molecular Endocrinology 5 1147-1157.

Rhéaume E, Simard J, Morel Y, Mebarki F, Zachmann M, Forest M, New MI \& Labrie F 1992 Congenital adrenal hyperplasia due to point mutations in the type II $3 \beta$-hydroxysteroid dehydrogenase gene. Nature Genetics 1 239-245.

Robinson MR \& Thomas BS 1971 Effect of hormone therapy on plasma testosterone levels in prostatic cancer. British Medical Journal 4 391-394.

Ross RK, Paganini-Hill A, Wan PC \& Pike MC 2000 Effect of hormone replacement therapy on breast cancer risk: estrogen versus estrogen plus progestin. Journal of the National Cancer Institute $\mathbf{9 2}$ 328-332.

Roy R, Dauvois S, Labrie F \& Bélanger A 1992 Estrogen-stimulated glucuronidation of dihydrotestosterone in MCF-7 human breast cancer cells. Journal of Steroid Biochemistry and Molecular Biology 41 $579-582$.

Roy J, Couillard S, Gutman M \& Labrie F 2003 A novel pure SERM achieves complete regression of the majority of human breast cancer tumors in nude mice. Breast Cancer Research and Treatment $\mathbf{8 1}$ 223-229.

Russell P \& Bannatyne P 1989 Surgical Pathology of the Ovaries. New York, Edinburgh: Churchill-Livingstone.

Savvas M, Studd JWW, Fogelman I, Dooley M, Montgomery J \& Murby B 1988 Skeletal effects of oral oestrogen compared with subcutaneous oestrogen and testosterone in postmenopausal women. British Medical Journal 297 331-333.

Schmitt B, Wilt TJ, Schellhammer PF, DeMasi V, Sartor O, Crawford ED \& Bennett CL 2001 Combined androgen blockade with nonsteroidal antiandrogens for advanced prostate cancer: a systematic review. Urology $\mathbf{5 7} 727-732$.

Schriock ED, Buffington CK, Hubert GD, Kurtz BR, Kitabchi AE, Buster JE \& Givens JR 1988 Divergent correlations of circulating dehydroepiandrosterone sulfate and testosterone with insulin levels and insulin receptor binding. Journal of Clinical Endocrinology and Metabolism 66 1329-1331. 
Schwartz AG, Pashko L \& Whitcomb JM 1986 Inhibition of tumor development by dehydroepiandrosterone and related steroids. Toxicologic Pathology 14 357-362.

Sherwin BB 1988 Affective changes with estrogen and androgen replacement therapy in surgically menopausal women. Journal of Affective Disorders 14 177-187.

Sherwin BB \& Gelfand MM 1984 Effects of parenteral administration of estrogen and androgen on plasma hormone levels and hot flushes in the surgical menopause. American Journal of Obstetrics and Gynecology 148 552-557.

Sherwin BB \& Gelfand MM 1985 Differential symptom response to parenteral estrogen and/or androgen administration in the surgical menopause. American Journal of Obstetrics and Gynecology 151 153-160.

Sherwin BB \& Gelfand MM 1987 The role of androgen in the maintenance of sexual functioning in oophorectomized women. Psychosomatic Medicine 49 397-409.

Shifren JL, Braunstein GD, Simon JA, Casson PR, Buster JE, Redmond GP, Burki RE, Ginsburg ES, Rosen RC, Leiblum SR et al. 2000 Transdermal testosterone treatment in women with impaired sexual function after oophorectomy. New England Journal of Medicine 343 682-688.

Shimokata H, Tobin JD, Muller DC, Elahi D, Coon PJ \& Andres R 1989 Studies in the distribution of body fat: I. Effects of age, sex, and obesity. Journal of Gerontology 44 M66-M73.

Simard J, Vincent A, Duchesne R \& Labrie F 1988 Full oestrogenic activity of $\mathrm{C}_{19}-\Delta^{5}$-adrenal steroids in rat pituitary lactotrophs and somatotrophs. Molecular and Cellular Endocrinology 55 233-242.

Simard J, Rhéaume E, Sanchez R, Laflamme N, de Launoit Y, Luu-The V, Van Seters AP, Gordon RD, Bettendorf M, Heinrich $\mathrm{U}$ et al. 1993 Molecular basis of congenital adrenal hyperplasia due to $3 \beta$-hydroxysteroid dehydrogenase deficiency. Molecular Endocrinology 7 716-728.

Simard J, Rhéaume E, Mébarki F, Sanchez R, New MI, Morel Y \& Labrie F 1995 Molecular basis of human 3ß-hydroxysteroid dehydrogenase deficiency. Journal of Steroid Biochemistry and Molecular Biology 53 127-138.

Sluijmer AV, Heineman MJ, Koudstaal J, Theunissen PH, de Jong FH \& Evers JL 1998 Relationship between ovarian production of estrone, estradiol, testosterone, and androstenedione and the ovarian degree of stromal hyperplasia in postmenopausal women. Menopause 5 207-210.

Soloway MS 1998 Combined androgen blockade: an optimal therapy for minimally advanced prostate cancer? British Journal of Urology 81 87-94; discussion 94-85.

Sourla A, Flamand M, Bélanger A \& Labrie F 1998 Effect of dehydroepiandrosterone on vaginal and uterine histomorphology in the rat. Journal of Steroid Biochemistry and Molecular Biology $\mathbf{6 6}$ $137-149$

Staubitz WJ, Oberkircher OJ \& Lent MH 1954 Clinical results of the treatment of prostatic carcinoma over a ten-year period. Journal of Urology 72 939-945.

Stomati M, Monteleone P, Casarosa E, Quirici B, Puccetti S, Bernardi F, Genazzani AD, Rovati L, Luisi M \& Genazzani AR 2000 Six-months oral dehydroepiandrosterone supplementation in early and late postmenopause. Gynecological Endocrinology 14 342-363.

Studd JW, Collins WP, Chakravarti S, Newton JR, Oram D \& Parsons A 1987 Estradiol and testosterone implants in treatment of psychosexual problems in postmenopausal woman. British Journal of Obstetrics and Gynaecology 84 314-315.

Suzuki T, Suzuki N, Daynes RA \& Engleman EG 1991 Dehydroepiandrosterone enhances IL2 production and cytotoxic effector function of human T cells. Clinical Immunology and Immunopathology 61 202-211.

Tchernof A \& Labrie F 2004 Dehydroepiandrosterone, obesity and cardiovascular disease risk. A review of human studies. European Journal of Endocrinology 151 1-14.
Tchernof A, Després JP, Bélanger A, Dupont A, Prud'homme D, Moorjani S, Lupien PJ \& Labrie F 1995 Reduced testosterone and adrenal C19 steroid levels in obese men. Metabolism 44 513-519.

Tchernof A, Labrie F, Bélanger A \& Després JP 1996 Obesity and metabolic complications: contribution of DHEA and other steroid hormones. Journal of Endocrinology 150 S155-S164.

Turgeon D, Carrier JS, Lévesque E, Beatty BG, Bélanger A \& Hum DW 2000 Isolation and characterization of the human UGT2B15 gene, localized within a cluster of UGT2B genes and pseudogenes on chromosome 4. Journal of Molecular Biology 295 489-504.

Turgeon D, Carrier JS, Levesque E, Hum DW \& Belanger A 2001 Relative enzymatic activity, protein stability, and tissue distribution of human steroid-metabolizing UGT2B subfamily members. Endocrinology 142 778-787.

VACURG 1967 Treatment and survival of patients with cancer of the prostate. Surgery Gynecology and Obstetrics 124 1011-1017.

Vermeulen A \& Verdonck L 1976 Radioimmunoassays of $17 \beta$ hydroxy-5 $\alpha$-androstan-3-one, 4-androstene-3,17-dione, dehydroepiandrosterone, 17 $\beta$-hydroxyprogesterone and progesterone and its application to human male plasma. Journal of Steroid Biochemistry 7 1-10.

Vermeulen A, Deslypene JP, Schelfhout W, Verdonck L \& Rubens R 1982 Adrenocortical function in old age: response to acute adrenocorticotropin stimulation. Journal of Clinical Endocrinology and Metabolism 54 187-191.

Villareal DT \& Holloszy JO 2004 Effect of DHEA on abdominal fat and insulin action in elderly women and men: a randomized controlled trial. Journal of the American Medical Association 292 2243-2248.

Villareal DT, Holloszy JO \& Kohrt WM 2000 Effects of DHEA replacement on bone mineral density and body composition in elderly women and men. Clinical Endocrinology 53 561-568.

Waxman JH, Wass JA, Hendry WF, Whitfield HN, Besser GM, Malpas JS \& Oliver RT 1983 Treatment with gonadotropinreleasing hormone analogue in advanced prostatic cancer. British Medical Journal (Clinical Research Edition) 286 1309-1312.

Weiss NS, Ure CL, Ballard JH, Williams AR \& Daling JR 1980 Decreased risk of fractures of the hip and lower forearm with postmenopausal use of estrogen. New England Journal of Medicine 303 $1195-1198$.

Wilson JD \& Walker JD 1969 The conversion of testosterone to $5 \alpha$-androstan-17 $\beta$-ol-3-one (dihydrotestosterone) by skin slices of man. Journal of Clinical Investigation 48 371-379.

Wilson JD, Griffin JE \& Russel DW 1993 Steroid 5a-reductase 2 deficiency. Endocrine Reviews 14 577-593.

Women's Health Initiative 2002 Risks and benefits of estrogen plus progestin in healthy postmenopausal women. Journal of the American Medical Association 288 321-333.

Wu L, Einstein M, Geissler WM, Chan KH, Elliston KO \& Andersson S 1993 Expression cloning and characterization of human $17 \beta$-hydroxysteroid dehydrogenase type 2 , a microsomal enzyme possessing 20 $\alpha$-hydroxysteroid dehydrogenase activity. Journal of Biological Chemistry 268 12964-12969.

Yen TT, Allan JA, Pearson DV, Acton JM \& Greenberg MM 1977 Prevention of obesity in Avy/a mice by dehydroepiandrosterone. Lipids 12 409-413.

Zhao HF, Rhéaume E, Trudel C, Couët J, Labrie F \& Simard J 1990 Structure and sexual dimorphic expression of a liver-specific rat $3 \beta$-hydroxysteroid dehydrogenase/isomerase. Endocrinology 127 3237-3239.

Zhao HF, Labrie C, Simard J, de Launoit Y, Trudel C, Martel C, Rhéaume E, Dupont E, Luu-The V, Pelletier G et al. 1991 Characterization of rat $3 \beta$-hydroxysteroid dehydrogenase $/ \Delta^{5}-\Delta^{4}$ isomerase cDNAs in steroidogenic and peripheral tissues. Journal of Biological Chemistry 266 583-593. 
Zhu DW, Lee X, Breton R, Ghosh D, Pangborn W, Duax WL \& Lin SX 1993 Crystallization and preliminary X-ray diffraction analysis of the complex of human placental $17 \beta$-hydroxysteroid dehydrogenase with NADP+. Journal of Molecular Biology 234 242-244.

Zumoff B, Levin J, Rosenfeld RS, Markham M, Strain GW \& Fukushima DK 1981 Abnormal 24-hr mean plasma concentrations of dehydroepiandrosterone and dehydroisoandrosterone sulfate in women with primary operable breast cancer. Cancer Research 41 3360-3363.

Received in final form 29 July 2005 Accepted 12 August 2005 